Keywords: plutonium, chloride, fluoride, vacuum, distillation

Retention: Permanent

\title{
Application of Vacuum Salt Distillation Technology for the Removal of Fluoride
}

R. A. Pierce, T. D. Caldwell, and D. J. Pak

August 2011

Savannah River National Laboratory

Savannah River Nuclear Solutions

Aiken, SC 29808

Prepared for the U.S. Department of Energy under contract number DE-AC09-08SR22470.

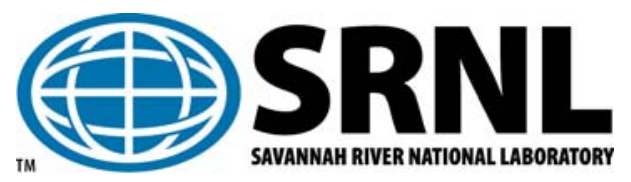




\section{DISCLAIMER}

This work was prepared under an agreement with and funded by the U.S. Government. Neither the U.S. Government or its employees, nor any of its contractors, subcontractors or their employees, makes any express or implied:

1. warranty or assumes any legal liability for the accuracy, completeness, or for the use or results of such use of any information, product, or process disclosed; or

2. representation that such use or results of such use would not infringe privately owned rights; or

3. endorsement or recommendation of any specifically identified commercial product, process, or service.

Any views and opinions of authors expressed in this work do not necessarily state or reflect those of the United States Government, or its contractors, or subcontractors.

\section{Printed in the United States of America}

Prepared for

U.S. Department of Energy 


\section{REVIEWS AND APPROVALS}

AUTHORS:

R.A. Pierce, Separations and Actinide Science Programs

Date

T.D. Caldwell, Separations and Actinide Science Programs

Date AWE Visiting Scientist

D.J. Pak, Mechanical Systems and Custom Equipment Development

Date

TECHNICAL REVIEW:

K.M. Taylor-Pashow, Technical Reviewer

Date

Separations and Actinide Science Programs

J.W. Christopher, Technical Reviewer

Date

HB-Line Engineering

APPROVAL:

S.D. Fink, Manager

Date

Separations and Actinide Science Programs

S.L. Marra, Manager

Date

Environmental \& Chemical Process Technology Research Programs

P.B. Andrews, Manager

Date

Materials Disposition Engineering 


\section{EXECUTIVE SUMMARY}

Vacuum distillation of chloride salts from plutonium oxide $\left(\mathrm{PuO}_{2}\right)$ and simulant $\mathrm{PuO}_{2}$ has been demonstrated and deployed at the Savannah River Site (SRS) for the removal of sodium chloride $(\mathrm{NaCl})$ and potassium chloride $(\mathrm{KCl})$. The application of vacuum salt distillation (VSD) is of continued interest to the HB-Line Facility and the Mixed Oxide Fuel Fabrication Facility (MFFF) at SRS for the disposition of excess fissile materials. Many of these materials contain chloride and fluoride salt concentrations which make them unsuitable for dissolution at MFFF without prior removal of the chloride and fluoride salts.

Chloride and fluoride salts of interest - plutonium trifluoride $\left(\mathrm{PuF}_{3}\right)$, calcium fluoride $\left(\mathrm{CaF}_{2}\right)$, and calcium chloride $\left(\mathrm{CaCl}_{2}\right)$ - are less-volatile than $\mathrm{NaCl}$ and $\mathrm{KCl}$. However, without increasing the operating temperature, the VSD technology has been successfully adapted for the handling of less-volatile halide salts. Experiments at the Savannah River National Laboratory (SRNL) demonstrated the chemistry for the removal of less-volatile halides and addressed the primary engineering questions associated with the change in the process chemistry.

SRNL has successfully demonstrated the removal of halide from $\mathrm{CaCl}_{2}, \mathrm{CaF}_{2}$ and $\mathrm{PuF}_{3}$ below $1000{ }^{\circ} \mathrm{C}$ using VSD technology. The level of halide removal has been more than adequate to meet the MOX fuel specification $(7500 \mathrm{mg} / \mathrm{kg}$ ) for fluoride. The removal of halide is facilitated by first reacting potassium hydroxide $(\mathrm{KOH})$ with $\mathrm{CaCl}_{2}, \mathrm{CaF}_{2}$, and $\mathrm{PuF}_{3}$ to form potassium fluoride $(\mathrm{KF})$ or potassium chloride $(\mathrm{KCl})$, water vapor, and an oxide; $\mathrm{KF}, \mathrm{KCl}$, and excess $\mathrm{KOH}$ can be removed by VSD.

Small-scale process demonstrations (25-30 g bulk feed) showed the removal of 45,000 mg/kg fluoride from $\mathrm{CaF}_{2}$ and $84,000 \mathrm{mg} / \mathrm{kg}$ chloride from $\mathrm{CaCl}_{2}$ to less than $4000 \mathrm{mg} / \mathrm{kg}$ using $40-60 \%$ molar excess of $\mathrm{KOH}$. Pilot-scale process demonstrations (100-270 g) using 40-60\% molar excess of $\mathrm{KOH}$ yielded better results than the small-scale tests. In a 269-g test with $40 \%$ molar excess of $\mathrm{KOH}$, chloride (as $\left.\mathrm{CaCl}_{2}\right)$ mixed with cerium oxide $\left(\mathrm{CeO}_{2}\right)$ - a surrogate for $\mathrm{PuO}_{2}-$ was reduced from $87,000 \mathrm{mg} / \mathrm{kg}$ to $516 \mathrm{mg} / \mathrm{kg}$. In a 220 -g test with $40 \%$ molar excess of $\mathrm{KOH}$, fluoride (as $\mathrm{CaF}_{2}$ ) mixed with $\mathrm{CeO}_{2}$ was reduced from $45,000 \mathrm{mg} / \mathrm{kg}$ to $<465 \mathrm{mg} / \mathrm{kg}$.

The introduction of $\mathrm{KOH}$ and its reaction byproducts requires some changes to the way the salts are deposited and removed. A removable liner with a system of multiple reusable baffles may be sufficient to accommodate most of the process changes. The reaction of $\mathrm{KOH}$ with halide salts also produces water vapor as a byproduct. Although this water vapor could cause issues with the existing dry vacuum pump used by HB-Line, the installation of a low-cost, disposable, in-line moisture absorbent should be sufficient to protect the pump.

SRNL proposes an ongoing development program using available equipment that has the same internal dimensions as the VSD unit deployed in HB-Line. The program will define physical and chemical parameters needed for scale-up and deployment of a system for fluoride removal. The majority of the work will be with non-radioactive materials. Small-scale tests with $\mathrm{PuO}_{2}$ and $\mathrm{PuF}_{3}$ will supplement the non-radioactive experiments. 


\section{TABLE OF CONTENTS}

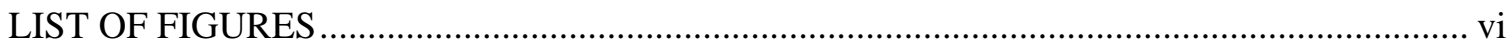

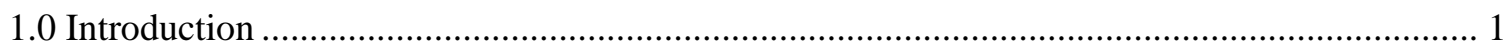

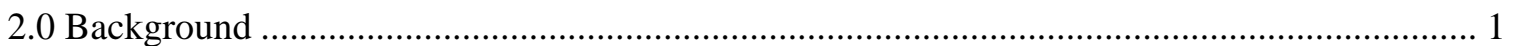

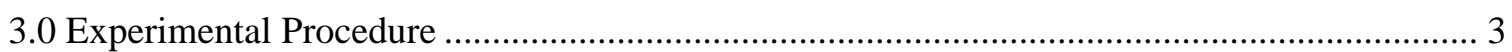

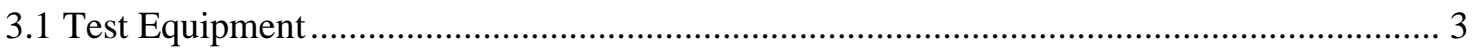

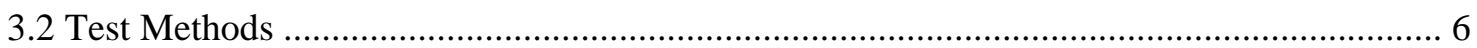

3.2.1 Distillation of Alkali Hydroxides and Alkali Fluorides ............................................... 6

3.2.2 Reaction of Halides with Alkali Hydroxide .................................................................. 7

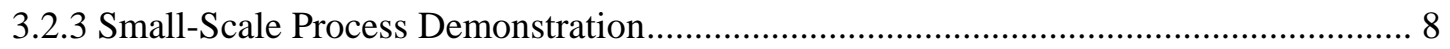

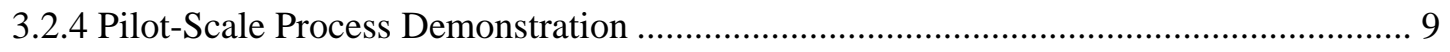

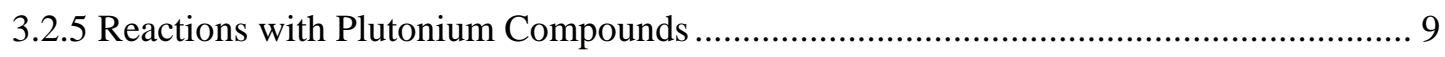

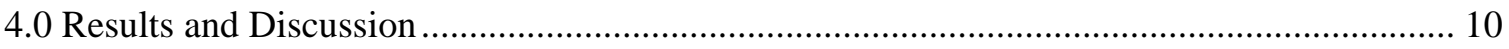

4.1 Distillation of Alkali Hydroxides and Alkali Fluorides.................................................... 10

4.2 Reaction of Halides with Alkali Hydroxide..................................................................... 10

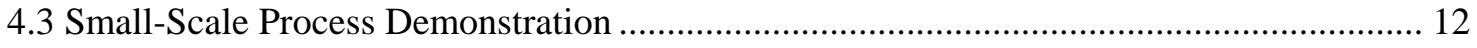

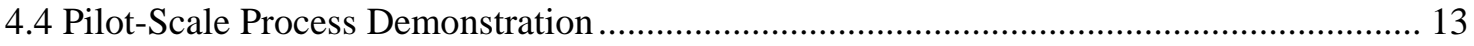

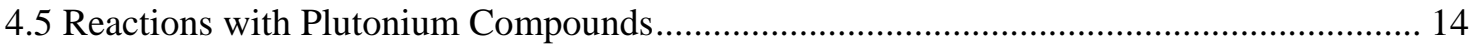

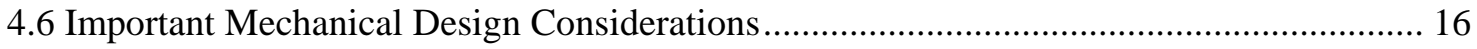

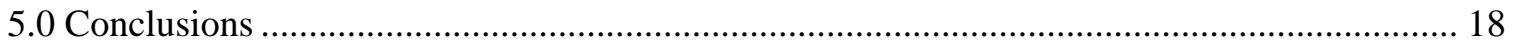

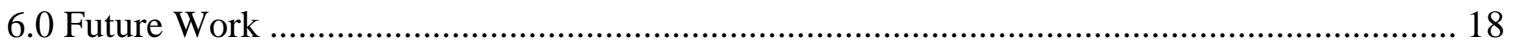

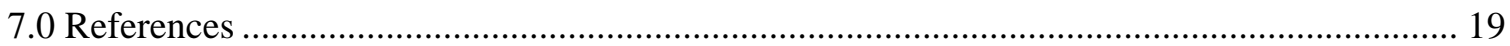




\section{LIST OF TABLES}

Table 3-1. Test Conditions for Reacting Alkali Hydroxide with Halide Salts .............................. 7

Table 3-2. Test Conditions for Reacting $\mathrm{KOH}$ with $\mathrm{CaF}_{2}$ in a $\mathrm{CeO}_{2}$ Matrix ................................. 8

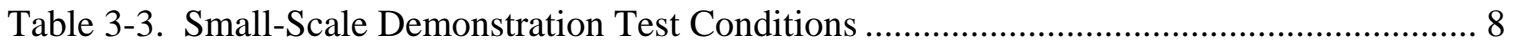

Table 3-4. Pilot-Scale Demonstration Test Conditions ................................................................ 9

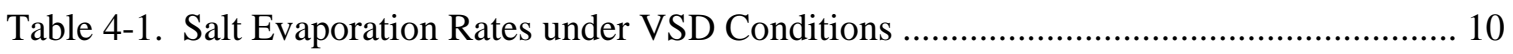

Table 4-2. Small-Scale Demonstration Test Conditions ............................................................. 12

Table 4-3. Pilot-Scale Demonstration Test Conditions .............................................................. 14

\section{LIST OF FIGURES}

Figure 2-1. Comparison of Chloride and Fluoride Salt Volatility ................................................ 2

Figure 2-2. Salt Volatility Comparisons for Fluoride Removal by VSD ..................................... 3

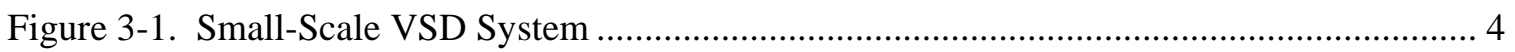

Figure 3-2. Intermediate-Scale Vacuum Chamber .......................................................................... 4

Figure 3-3. Intermediate-Scale System ….......................................................................... 5

Figure 3-4. Removable Liner with Simple Baffle Plates.............................................................. 5

Figure 3-5. Removable Liner with Simple Baffle Plate (installed) / Modified Baffle Plate .......... 6

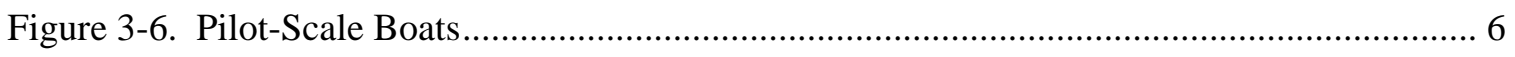

Figure 4-1. Product from Reaction of $\mathrm{CeF}_{3}$ with $\mathrm{KOH}$ followed by VSD .................................. 11

Figure 4-2. Product from Reaction of $\mathrm{CaF}_{2}$ with $\mathrm{KOH}$ followed by VSD .................................. 11

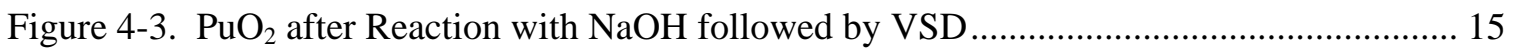

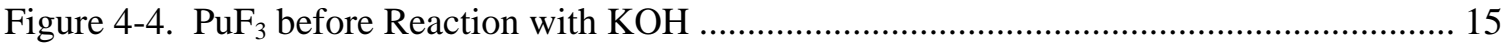

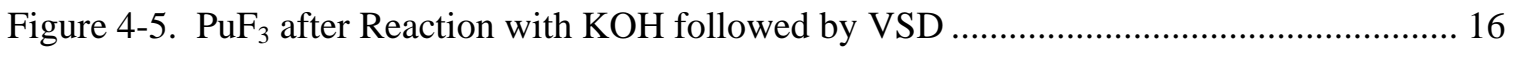

Figure 4-6. Successful Baffle Configuration inside Removable Liner........................................ 17

Figure 4-7. Salt Deposition Pattern inside Removable Liner ...................................................... 17 


\section{LIST OF ABBREVIATIONS}

$\begin{array}{ll}\text { AD } & \text { Analytical Development } \\ \text { DI } & \text { de-ionized } \\ \text { DOE } & \text { Department of Energy } \\ \text { IC } & \text { ion chromatography } \\ \text { ID } & \text { inside diameter } \\ \text { MFFF } & \text { MOX Fuel Fabrication Facility } \\ \text { MOX } & \text { mixed oxide } \\ \text { NM } & \text { not measured } \\ \text { OD } & \text { outside diameter } \\ \text { SRNL } & \text { Savannah River National Laboratory } \\ \text { SRS } & \text { Savannah River Site } \\ \text { VSD } & \text { vacuum salt distillation } \\ \text { XRD } & \text { X-ray diffraction }\end{array}$




\subsection{Introduction}

Vacuum distillation of chloride salts from plutonium oxide $\left(\mathrm{PuO}_{2}\right)$ and simulant $\mathrm{PuO}_{2}$ has been previously demonstrated at Department of Energy (DOE) sites using kilogram quantities of chloride salt. ${ }^{[1-2]}$ The apparatus for vacuum distillation contains a zone heated using a furnace and a zone actively cooled using either recirculated water or compressed air. During a vacuum distillation operation, a sample boat containing the feed material is placed into the apparatus while it is cool, and the system is sealed. The system is evacuated using a vacuum pump. Once a sufficient vacuum is attained, heating begins. Volatile salts distill from the heated zone to the cooled zone where they condense, leaving behind the non-volatile materials in the feed boat.

The application of vacuum salt distillation (VSD) is of interest to the HB-Line Facility and the MOX Fuel Fabrication Facility (MFFF) at the Savannah River Site (SRS). Both facilities are involved in efforts to disposition excess fissile materials. Many of these materials contain chloride and fluoride salt concentrations which make them unsuitable for dissolution without prior removal of the chloride and fluoride salts.

Between September 2009 and January 2011, the Savannah River National Laboratory (SRNL) and HB-Line designed, developed, tested, and successfully deployed a system for the distillation of chloride salts. ${ }^{[3]}$ Subsequent efforts are attempting to adapt the technology for the removal of fluoride. Fluoride salts of interest are less-volatile than the corresponding chloride salts. Consequently, an alternate approach is required for the removal of fluoride without significantly increasing the operating temperature.

HB-Line Engineering requested SRNL to evaluate and demonstrate the feasibility of an alternate approach using both non-radioactive simulants and plutonium-bearing materials. ${ }^{[4-5]}$ Whereas the earlier developments targeted the removal of sodium chloride $(\mathrm{NaCl})$ and potassium chloride $(\mathrm{KCl})$, the current activities are concerned with the removal of the halide ions associated with plutonium trifluoride $\left(\mathrm{PuF}_{3}\right)$, plutonium tetrafluoride $\left(\mathrm{PuF}_{4}\right)$, calcium fluoride $\left(\mathrm{CaF}_{2}\right)$, and calcium chloride $\left(\mathrm{CaCl}_{2}\right)$.

This report discusses non-radioactive testing of small-scale and pilot-scale systems and radioactive testing of a small-scale system. Experiments focused on demonstrating the chemistry for halide removal and addressing the primary engineering questions associated with a change in the process chemistry.

\subsection{Background}

VSD technology takes advantage of the large difference in volatility between alkali halide salts and $\mathrm{PuO}_{2}$. As has been demonstrated, $\mathrm{NaCl}$ and $\mathrm{KCl}$ are sufficiently volatile that they can be distilled from $\mathrm{PuO}_{2}$ at a satisfactory rate under vacuum above $900{ }^{\circ} \mathrm{C}$. ${ }^{[6]}$ Alkaline-earth halides and actinide halides also have a large enough difference in volatility from $\mathrm{PuO}_{2}$ to enable distillation; however, they are not sufficiently volatile below $1000^{\circ} \mathrm{C}$ to allow distillation at a rate sufficient for production-scale operations in HB-Line. A comparison of volatility of chloride and fluoride salts is shown in Figure 2-1. ${ }^{[7]}$ 


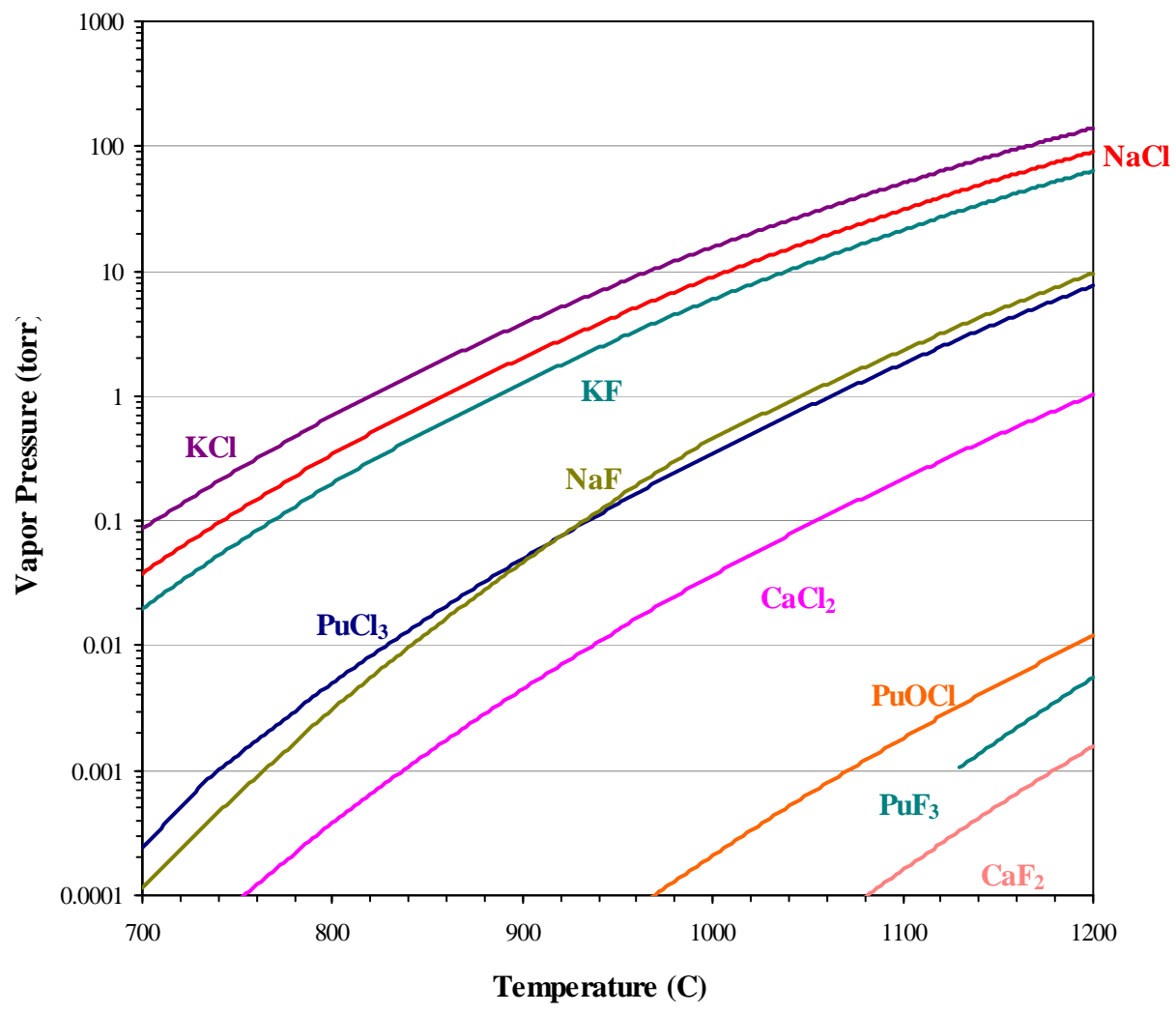

Figure 2-1. Comparison of Chloride and Fluoride Salt Volatility

It was shown during the development of a sodium peroxide $\left(\mathrm{Na}_{2} \mathrm{O}_{2}\right)$ fusion method for the dissolution of $\mathrm{PuO}_{2}$ materials that alkaline earth and lanthanide halide salts would react with $\mathrm{Na}_{2} \mathrm{O}_{2}$ to form $\mathrm{NaCl}$ and the corresponding alkaline earth or actinide oxide. ${ }^{[8]}$ It was speculated that sodium hydroxide $(\mathrm{NaOH})$ or $\mathrm{KOH}$ might react in a similar manner with $\mathrm{CaCl}_{2}$ and $\mathrm{PuF}_{3}$ according to reactions 1 and 2 .

$$
\begin{aligned}
& \mathrm{CaF}_{2}+2 \mathrm{KOH} \rightarrow \mathrm{CaO}+2 \mathrm{KF}+\mathrm{H}_{2} \mathrm{O} \\
& 2 \mathrm{PuF}_{3}+6 \mathrm{KOH}+1 / 2 \mathrm{O}_{2} \rightarrow 2 \mathrm{PuO}_{2}+6 \mathrm{KF}+3 \mathrm{H}_{2} \mathrm{O}
\end{aligned}
$$

If reaction 1 occurs, the less-volatile alkaline earth and actinide halide salts can be converted to oxides and the associated halide exchanged to form either $\mathrm{KF}$ or $\mathrm{NaF}$, which may be sufficiently volatile below $1000{ }^{\circ} \mathrm{C}$. Furthermore, $\mathrm{KOH}$ is more volatile than $\mathrm{KF}$ or NaF, which offers the potential for excess $\mathrm{KOH}$ to be distilled along with $\mathrm{KF}$ or NaF. Figure 2-2 shows the relative volatility of $\mathrm{KOH}$ and the relevant halide salts from Figure $2-1 .^{[7]}$ The net result is that the distilled product shows a change from $\mathrm{CaCl}_{2}$ and $\mathrm{CaF}_{2}$ to $\mathrm{CaO}$ and from $\mathrm{PuCl}_{3}$ and $\mathrm{PuF}_{3}$ to $\mathrm{PuO}_{2}$. $\mathrm{PuO}_{2}$ is not shown in Figure 2-1 because the volatility of $\mathrm{PuO}_{2}$ is about seven of orders of magnitude lower than $\mathrm{CaF}_{2}$ (to the right of $\mathrm{CaF}_{2}$ in Figure 2-1); for comparison, the volatility of $\mathrm{CaF}_{2}$ is about seven orders of magnitude lower than $\mathrm{KCl}$ and $\mathrm{NaCl}$.

The literature indicates that $\mathrm{PuF}_{4}$ will not be present in materials subjected to the 3013 process because it decomposes to $\mathrm{PuO}_{2}$ at the temperatures used $\left(>750{ }^{\circ} \mathrm{C}\right.$ for two hours) in the 3013 stabilization process. ${ }^{[9]}$ If it were, it is fully expected that any $\mathrm{PuF}_{4}$ present would react similar to reaction 1 . 


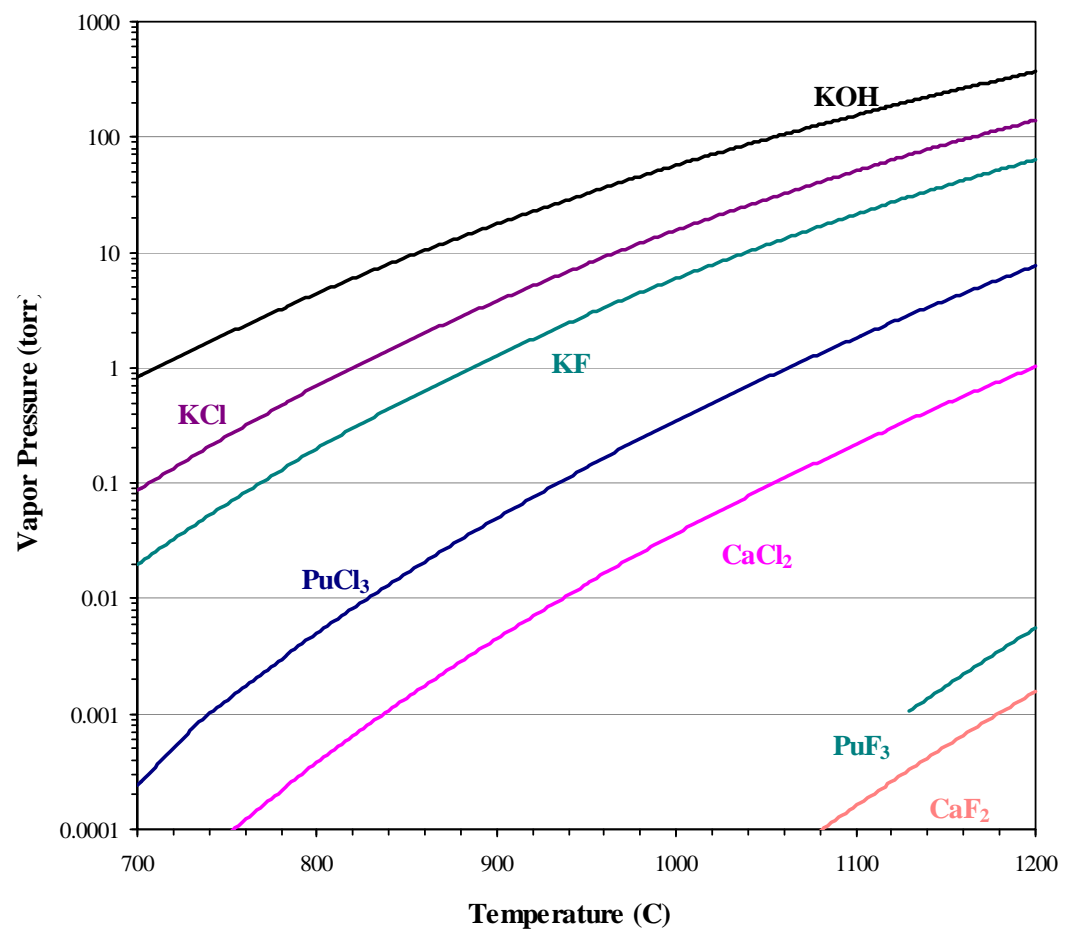

Figure 2-2. Salt Volatility Comparisons for Fluoride Removal by VSD

\subsection{Experimental Procedure}

\subsection{Test Equipment}

Three different test units were used: 1) a non-radioactive small-scale unit, 2) a non-radioactive pilot-scale unit of dimensions similar to the VSD unit deployed in HB-Line, and 3) a radioactive small-scale unit. The non-radioactive small-scale distillation unit was fabricated from Alloy 600 by the SRNL Machine Shop and consisted of a 5-cm inside diameter (ID) heated zone (23 cm long) which opened up to a $8.5-\mathrm{cm}$ ID cooled zone ( $21 \mathrm{~cm}$ long). The apparatus used a stainlesssteel cooling coil wrapped around the outside of the 8.5- $\mathrm{cm}$ ID section and was cooled using $20{ }^{\circ} \mathrm{C}$ water. During testing, the system was closed and evacuated using a Pyrex ${ }^{\mathrm{TM}}$ end-flange and Viton ${ }^{\mathrm{TM}}$ o-ring. The end-flange was held in place only by the vacuum, negating the need for additional over-pressure protection measures. The end-flange was designed to enable the operator to view the interior of the VSD unit during testing. A photograph of the VSD setup is shown in Figure 3-1. 


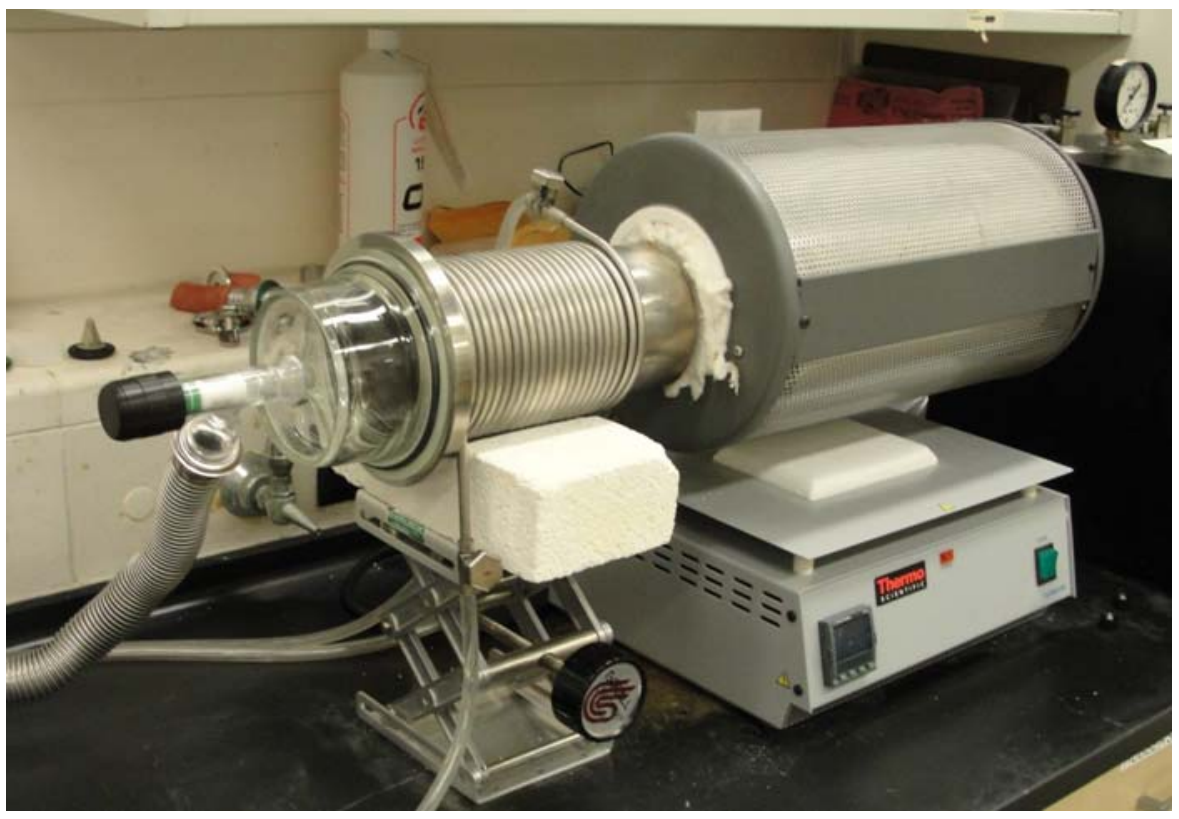

Figure 3-1. Small-Scale VSD System

The non-radioactive pilot-scale system was fabricated from Alloys 600 and 690 by the SRNL Machine Shop. Its physical dimensions and features correspond to the vacuum chamber deployed in HB-Line. It consisted of a $28-\mathrm{cm}$ long 7.5- $\mathrm{cm}$ ID heated zone which opened to a 53-cm long $10-\mathrm{cm}$ ID cooled zone. The cooled zone contained $32 \mathrm{~cm}$ of $6.4-\mathrm{mm}$ stainless-steel cooling coil wrapped around it. The VSD vacuum chamber was heated using a Carbolite GHC 12/450 threezone tube furnace rated at $3120 \mathrm{~W}$. It was cooled with either $20^{\circ} \mathrm{C}$ water or compressed air. The system was evacuated using an Edwards RV5 oil vacuum pump. The vacuum pump was connected to the vacuum chamber using stainless-steel bellows hose. A picture of the vacuum chamber is shown in Figure 3-2, and a picture of the VSD apparatus in the furnace is provided in Figure 3-3. The end cap was fabricated from 304L stainless steel with a groove for a Viton ${ }^{\mathrm{TM}}$ oring. Vacuum was measured adjacent to the flange with an Edwards Pirani ${ }^{\mathrm{TM}}$ gauge.

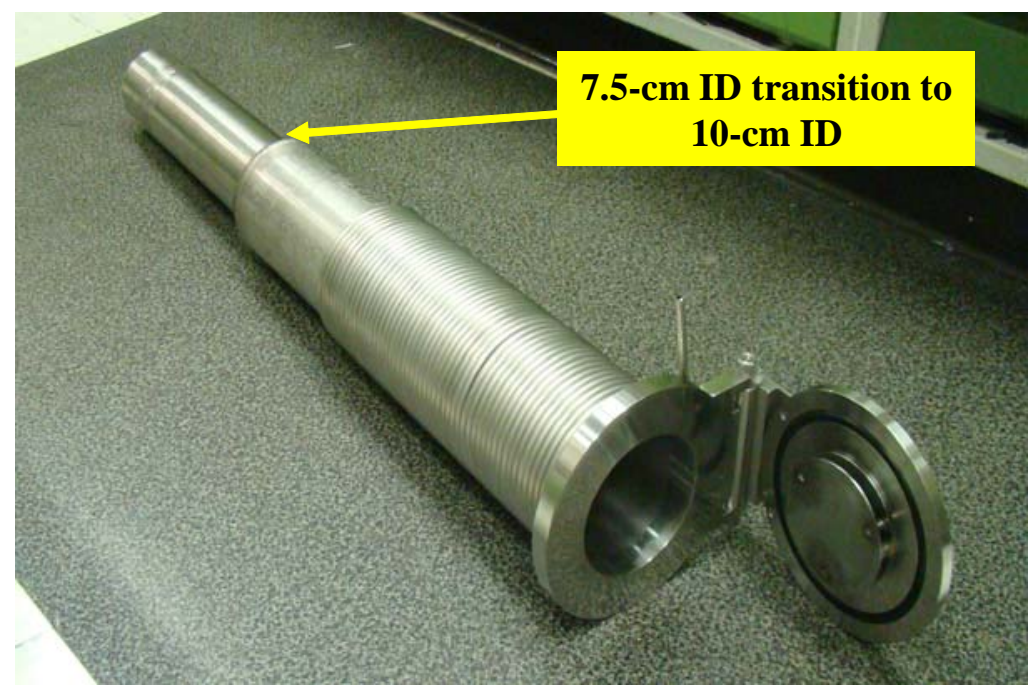

Figure 3-2. Intermediate-Scale Vacuum Chamber 


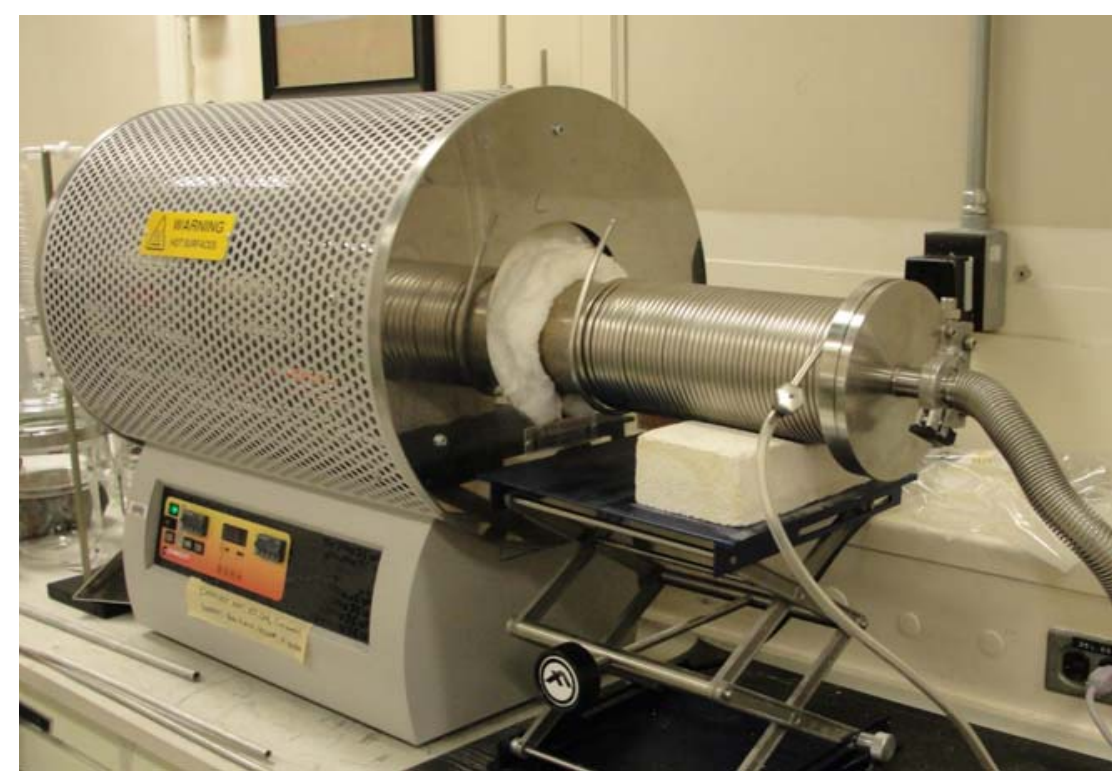

Figure 3-3. Intermediate-Scale System

The radioactive small-scale unit has dimensions similar to that of the non-radioactive small scale unit with the exception of the cooled section being $38 \mathrm{~cm}$ long instead of $21 \mathrm{~cm}$. Pictures and a discussion of the details of the unit are provided elsewhere. ${ }^{[10]}$

For pilot-scale testing, a removable liner was used for salt collection. The liner was fabricated from 304L stainless steel. Inside the liner were placed simple baffles also fabricated from 304L stainless steel. The liner and simple baffles are shown in Figure 3-4. The liner had a 9-cm outside diameter (OD) with rails on the outside to center the liner inside the 10-cm ID of the vacuum chamber [Figure 3-5]. A modified baffle, shown in Figure 3-5, was also tested.

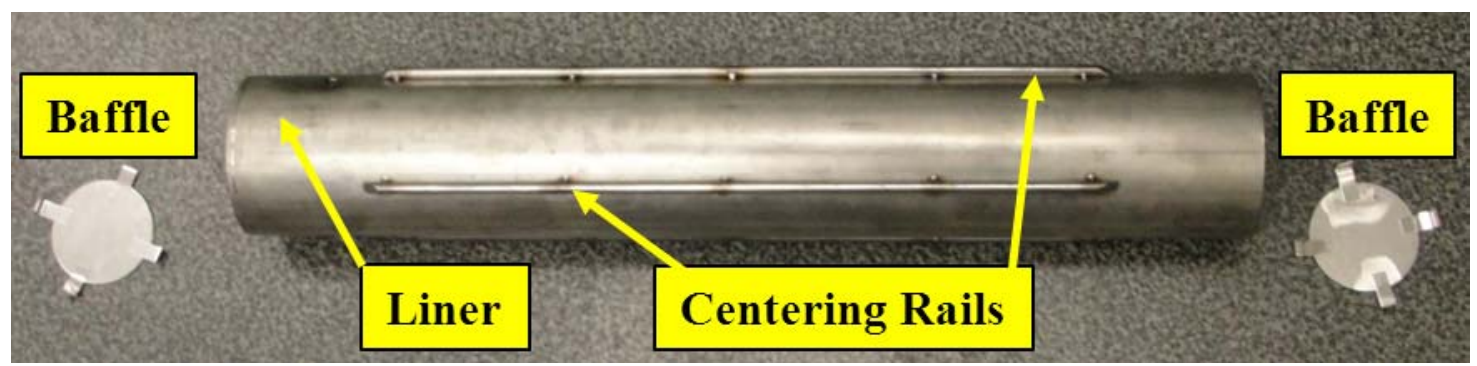

Figure 3-4. Removable Liner with Simple Baffle Plates 

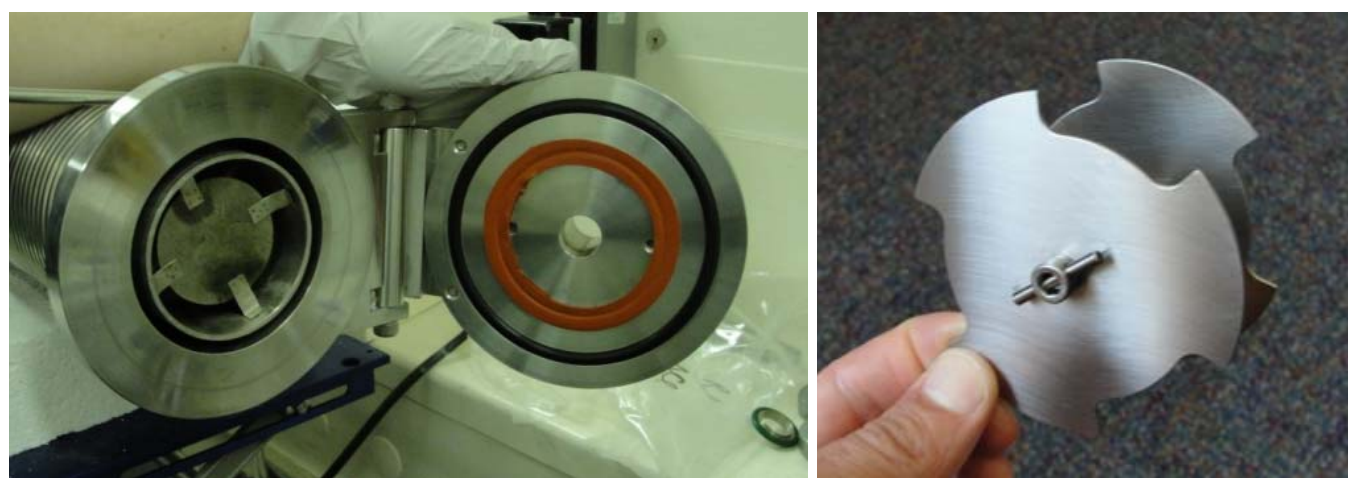

Figure 3-5. Removable Liner with Simple Baffle Plate (installed) / Modified Baffle Plate

Small-scale tests used either quartz or alumina boats with a quartz cover. The small-scale boats were nominally $12 \mathrm{~cm}$ long, $2.5 \mathrm{~cm}$ wide, and $2 \mathrm{~cm}$ deep. Pilot-scale tests used two similar boat designs during testing (Figure 3-6). The pilot-scale boats employed a two-piece lid design to create a tortuous path for any entrained oxide in the halide vapor phase to leave the boat. The first boat was $15 \mathrm{~cm}$ long, $7 \mathrm{~cm}$ wide, and $2 \mathrm{~cm}$ deep alumina with Alloy 600 lids.
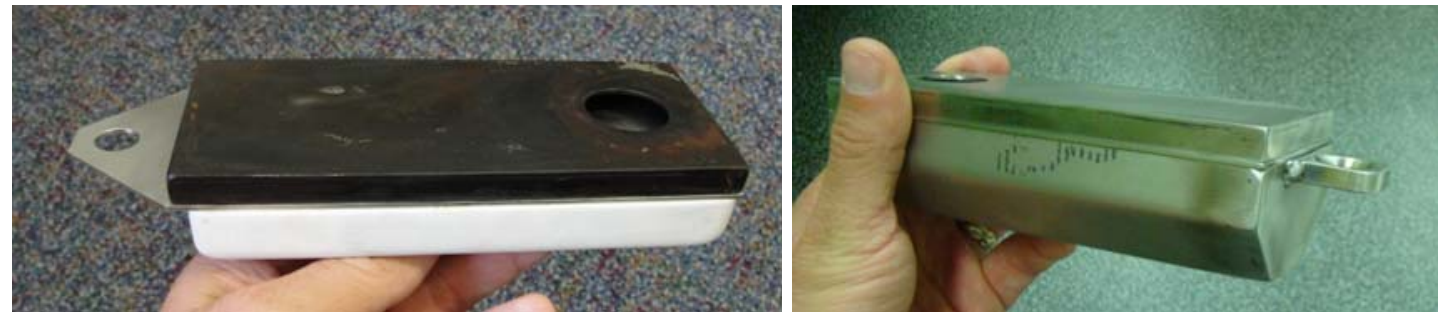

Figure 3-6. Pilot-Scale Boats

The second pilot-scale boat is a 15-cm long, 6.5-cm wide boat fabricated from Alloy 600 by the SRNL Machine Shop (Figure 3-6). The boat has a semi-octagonal cross section to provide a stable base. The boat is a shortened version of the design used in HB-Line.

\section{2 $\underline{\text { Test Methods }}$}

\subsubsection{Distillation of Alkali Hydroxides and Alkali Fluorides}

The relative distillation rates of $\mathrm{KF}$ and $\mathrm{NaF}$ were measured at $850-1000{ }^{\circ} \mathrm{C}$. Similarly, the relative distillation rates of $\mathrm{KOH}$ and $\mathrm{NaOH}$ from $\mathrm{CeO}_{2}$, a surrogate for $\mathrm{PuO}_{2}$, were measured at $700-900{ }^{\circ} \mathrm{C}$. Comparison of the distillation rates enables a decision regarding a preference for the use of $\mathrm{KOH}$ or $\mathrm{NaOH}$ as the reactant.

Distillation experiments with $\mathrm{KF}$ and $\mathrm{NaF}$ were completed in the small-scale VSD unit. For KF or NaF distillation, 5-13 g of alkali halide was placed in a weighed alumina boat. The boat was placed in the VSD vacuum chamber and the door closed. The chamber was heated to the test temperature. Once at temperature, the vacuum pump was turned on and the salt was distilled for $20 \mathrm{~min}$. After $20 \mathrm{~min}$, the vacuum was released and the furnace turned off to allow the boat to cool. The final weight of the boat and salt were recorded and the distillation rate calculated.

Distillation experiments with $\mathrm{KOH}$ and $\mathrm{NaOH}$ in a $\mathrm{CeO}_{2}$ matrix were completed in the pilot-scale VSD unit. For each test, 6-15 g of hydroxide salt were mixed with 10-15 g of $\mathrm{CeO}_{2}$ in an alumina 
boat. The boat was placed in the VSD vacuum chamber and the door closed. The chamber was heated to the test temperature. Once at temperature, the vacuum was turned on and the salt was distilled for 20-45 min (20 min for tests with $10 \mathrm{~g}$ of $\mathrm{CeO}_{2}$ and 45 min for tests with $15 \mathrm{~g}$ of $\mathrm{CeO}_{2}$ ). After 20-45 min, the vacuum was released and the furnace turned off to allow the boat to cool. The final weight of the boat and salt were recorded and the distillation rate calculated.

\subsubsection{Reaction of Halides with Alkali Hydroxide}

The reaction of either $\mathrm{NaOH}$ or $\mathrm{KOH}$ with $\mathrm{CaCl}_{2}, \mathrm{CaF}_{2}$, and $\mathrm{CeF}_{3}$ - the latter a surrogate for $\mathrm{PuF}_{3}$ - was studied. For these tests, known amounts of alkali hydroxide and halide salt were combined in a small alumina boat. They were placed into the pilot-scale vacuum chamber and the door closed. Based on previous work studying the reaction of sodium peroxide with halide salt, ${ }^{[8]}$ the boat and contents were heated to $700{ }^{\circ} \mathrm{C}$ in air at atmospheric pressure. The boat was held at temperature for $30 \mathrm{~min}$. Next, vacuum was applied and the boat heated to $980{ }^{\circ} \mathrm{C}$ for $30 \mathrm{~min}$. The boat was then cooled under vacuum. The products remaining in the boat from the $\mathrm{CaF}_{2}$ and $\mathrm{CeF}_{3}$ tests were analyzed using $\mathrm{X}$-ray diffraction (XRD).

The product remaining in the boat from the $\mathrm{CaCl}_{2}$ test was analyzed for chloride concentration. The chloride content of the product was measured as follows. A sample of the oxide product was weighed into a plastic centrifuge tube with a screw-on cap. De-ionized (DI) water was added to the centrifuge tube and weighed. The screw cap was secured onto the tube and the tube was shaken vigorously for $3 \mathrm{~min}$. Next, the chloride concentration of the water was tested using a Hach QuanTab ${ }^{\circledR}$ chloride test strip. The validity of this method was demonstrated during an earlier study. ${ }^{[6]}$ The quantities of reactants for each test are listed in Table 3-1.

Table 3-1. Test Conditions for Reacting Alkali Hydroxide with Halide Salts

\begin{tabular}{|c|c|c|c|c|}
\hline Halide Salt & $\begin{array}{c}\text { Halide Salt } \\
\text { Mass (g) }\end{array}$ & Alkali Hydroxide & $\begin{array}{c}\text { Alkali Hydroxide } \\
\text { Mass (g) }\end{array}$ & $\begin{array}{c}\text { Product } \\
\text { Mass (g) }\end{array}$ \\
\hline $\mathrm{CaF}_{2}$ & 2.0159 & $\mathrm{KOH}$ & 9.1082 & 1.4359 \\
\hline $\mathrm{CeF}_{3}$ & 3.0203 & $\mathrm{KOH}$ & 9.0688 & 3.8595 \\
\hline $\mathrm{CaCl}_{2}$ & 2.9731 & $\mathrm{NaOH}$ & 8.8293 & 1.3333 \\
\hline
\end{tabular}

Based on alkali halide distillation results (Section 3.2.1), the temperature of reaction for $\mathrm{KOH}$ with $\mathrm{CaF}_{2}$ was studied to determine if the reaction would occur in the $\mathrm{CeO}_{2}$ matrix before appreciable volatilization of $\mathrm{KOH}$ occurred under vacuum. Four parallel experiments were performed by combining $\mathrm{KOH}, \mathrm{CaF}_{2}$, and $\mathrm{CeO}_{2}$ in a zirconium metal crucible, heating the crucible to a specified temperature in air using a muffle furnace, removing the crucible from the furnace, and analyzing the reaction products with XRD.

The contents of the four crucibles were weighed and the loaded crucible placed in the muffle furnace. The crucibles were heated in air to $400{ }^{\circ} \mathrm{C}$ and held at temperature for $20 \mathrm{~min}(\mathrm{KOH}$ melts at $360{ }^{\circ} \mathrm{C}$ ). After $20 \mathrm{~min}$ at temperature, one of the crucibles was removed from the furnace and placed in a desiccator to cool. Next, the furnace was heated to $475{ }^{\circ} \mathrm{C}$ and held for $20 \mathrm{~min}$. After $20 \mathrm{~min}$, a second crucible was removed and placed in the desiccator. The procedure was repeated at $550{ }^{\circ} \mathrm{C}$ and $625{ }^{\circ} \mathrm{C}$. The crucibles and contents were all analyzed using XRD. The test conditions are listed in Table 3-2. 
Table 3-2. Test Conditions for Reacting $\mathrm{KOH}$ with $\mathrm{CaF}_{2}$ in a $\mathrm{CeO}_{2} \mathrm{Matrix}$

\begin{tabular}{|c|c|c|c|c|}
\hline Reaction Temp & $400{ }^{\circ} \mathrm{C}$ & $475{ }^{\circ} \mathrm{C}$ & $550{ }^{\circ} \mathrm{C}$ & $625{ }^{\circ} \mathrm{C}$ \\
\hline $\mathbf{C a F}_{\mathbf{2}}$ (g) & 0.2015 & 0.2035 & 0.2054 & 0.2003 \\
\hline $\mathbf{C e O}_{2}$ (g) & 2.0189 & 2.0086 & 2.0242 & 2.0038 \\
\hline $\mathbf{K O H}$ (g) & 0.4460 & 0.4452 & 0.5345 & 0.5382 \\
\hline
\end{tabular}

\subsubsection{Small-Scale Process Demonstration}

Small-scale demonstrations were completed in the small-scale VSD unit using small quartz crucibles. Each test started with $\sim 21.5 \mathrm{~g}$ of $\mathrm{CeO}_{2}$. The $\mathrm{CeO}_{2}$ was then added and mixed with either 3.1-3.4 $\mathrm{g}$ of $\mathrm{CaCl}_{2}$ or $\sim 2.2 \mathrm{~g}$ of $\mathrm{CaF}_{2}$. Last, $\mathrm{KOH}$ was added. The amount of $\mathrm{KOH}$ was calculated based on the mole ratios of reaction 1 plus varying amounts of excess $\mathrm{KOH}$. The location of the $\mathrm{KOH}$ varied. Some tests added the $\mathrm{KOH}$ on top of the $\mathrm{CeO}_{2}$ mixture, other tests added it to the bottom of the crucible before the $\mathrm{CeO}_{2}$ mixture was added, and most tests involved mixing the $\mathrm{KOH}$ into the $\mathrm{CeO}_{2}$ mixture. The masses of reactants and locations of $\mathrm{KOH}$ are provided in Table 3-3. Table 3-3 also contains information on the heating cycles of each test.

Table 3-3. Small-Scale Demonstration Test Conditions

\begin{tabular}{|c|c|c|c|c|c|c|c|}
\hline Test & $\begin{array}{c}\mathrm{CeO}_{2} \\
(\mathrm{~g})\end{array}$ & $\begin{array}{c}\text { Halide } \\
\text { Salt }\end{array}$ & $\begin{array}{c}\text { Halide } \\
\text { Salt } \\
\text { (g) }\end{array}$ & $\begin{array}{c}\mathrm{KOH} \\
(\mathrm{g})\end{array}$ & $\begin{array}{c}\text { mol } \\
\text { KOH } \\
\text { per mol } \\
\text { halide }\end{array}$ & $\begin{array}{c}\mathrm{KOH} \\
\text { location }\end{array}$ & Heating Cycle \\
\hline 1 & 21.52 & $\mathrm{CaCl}_{2}$ & 3.39 & 3.43 & 1.0 & top & To $950^{\circ} \mathrm{C}$ (vacuum) \\
\hline 2 & 21.51 & $\mathrm{CaCl}_{2}$ & 3.42 & 3.46 & 1.0 & bottom & To $950{ }^{\circ} \mathrm{C}$ (vacuum) \\
\hline 3 & 21.50 & $\mathrm{CaCl}_{2}$ & 3.41 & 3.42 & 1.0 & bottom & To $950^{\circ} \mathrm{C}$ (vacuum) \\
\hline 4 & 21.51 & $\mathrm{CaCl}_{2}$ & 3.41 & 3.46 & 1.0 & mixed & To $950^{\circ} \mathrm{C}$ (vacuum) \\
\hline 5 & 21.51 & $\mathrm{CaCl}_{2}$ & 3.41 & 3.43 & 1.0 & mixed & $\begin{array}{l}\text { To } 600^{\circ} \mathrm{C} \text { (vacuum) for } 30 \mathrm{~min} \text {; to } 950^{\circ} \mathrm{C} \\
\text { (vacuum) }\end{array}$ \\
\hline 6 & 21.50 & $\mathrm{CaCl}_{2}$ & 3.41 & 3.43 & 1.0 & mixed & To $450^{\circ} \mathrm{C}(\mathrm{atm})$ for $30 \mathrm{~min}$; to $950^{\circ} \mathrm{C}$ (vacuum) \\
\hline 7 & 21.51 & $\mathrm{CaCl}_{2}$ & 3.41 & 3.47 & 1.0 & mixed & To $450{ }^{\circ} \mathrm{C}$ (atm) for $30 \mathrm{~min}$; to $950^{\circ} \mathrm{C}$ (vacuum) \\
\hline 8 & 21.51 & $\mathrm{CaCl}_{2}$ & 3.14 & 5.18 & 1.6 & mixed & To $950^{\circ} \mathrm{C}$ (vacuum) \\
\hline 9 & 21.50 & $\mathrm{CaCl}_{2}$ & 3.15 & 5.14 & 1.6 & bottom & To $700^{\circ} \mathrm{C}(\mathrm{atm})$ for $10 \mathrm{~min}$; to $950^{\circ} \mathrm{C}$ (vacuum) \\
\hline 10 & 21.51 & $\mathrm{CaCl}_{2}$ & 3.12 & 5.19 & 1.6 & mixed & To $700{ }^{\circ} \mathrm{C}(\mathrm{atm})$ for $10 \mathrm{~min}$; to $950^{\circ} \mathrm{C}$ (vacuum) \\
\hline 11 & 21.51 & $\mathrm{CaCl}_{2}$ & 3.16 & 7.60 & 2.4 & mixed & To $700^{\circ} \mathrm{C}(\mathrm{atm})$ for $10 \mathrm{~min}$; to $950^{\circ} \mathrm{C}$ (vacuum) \\
\hline 12 & 21.51 & $\mathrm{CaF}_{2}$ & 2.19 & 3.14 & 1.0 & mixed & To $700^{\circ} \mathrm{C}(\mathrm{atm})$ for $10 \mathrm{~min}$; to $950^{\circ} \mathrm{C}$ (vacuum) \\
\hline 13 & 21.50 & $\mathrm{CaF}_{2}$ & 2.19 & 4.40 & 1.4 & mixed & To $700^{\circ} \mathrm{C}(\mathrm{atm})$ for $10 \mathrm{~min}$; to $950^{\circ} \mathrm{C}$ (vacuum) \\
\hline $13 \mathrm{~b}$ & \multicolumn{6}{|c|}{ Continuation of previous test } & To $700{ }^{\circ} \mathrm{C}(\mathrm{atm})$ for $10 \mathrm{~min}$; to $950^{\circ} \mathrm{C}$ (vacuum) \\
\hline 14 & 21.51 & $\mathrm{CaF}_{2}$ & 2.19 & 5.66 & 1.8 & mixed & To $700^{\circ} \mathrm{C}(\mathrm{atm})$ for $10 \mathrm{~min}$; to $950^{\circ} \mathrm{C}$ (vacuum) \\
\hline $14 \mathrm{~b}$ & \multicolumn{6}{|c|}{ Continuation of previous test } & To $700^{\circ} \mathrm{C}(\mathrm{atm})$ for $10 \mathrm{~min}$; to $950^{\circ} \mathrm{C}$ (vacuum) \\
\hline
\end{tabular}

Following the distillation experiment, the concentration of chloride or fluoride in the product boat was measured. The chloride content of the $\mathrm{CeO}_{2}$ was measured as follows. A sample of the distilled oxide was weighed into a plastic centrifuge tube with a screw-on cap. De-ionized (DI) water was added to the centrifuge tube and weighed. The screw cap was secured onto the tube and the tube was shaken vigorously for $3 \mathrm{~min}$. Next, the chloride concentration of the water was tested using a Hach QuanTab ${ }^{\circledR}$ chloride test strip. The fluoride concentration was analyzed by 
Analytical Development (AD). The sample was digested ( $\sim 0.5 \mathrm{~g}$ in $10 \mathrm{~mL}$ of $\sim 1 \mathrm{M}$ sulfuric acid $\left[\mathrm{H}_{2} \mathrm{SO}_{4}\right]$ for $3 \mathrm{~h}$ at $115^{\circ} \mathrm{C}$ ), and the resulting solution analyzed by ion chromatography (IC).

\subsubsection{Pilot-Scale Process Demonstration}

Pilot-scale demonstrations were completed in the pilot-scale VSD unit using boats with a twopiece lid (see Figure 3-6). Each test started with a selected amount of $\mathrm{CeO}_{2}$. We then added and mixed into the $\mathrm{CeO}_{2}$ a pre-determined amount of either $\mathrm{CaCl}_{2}$ or $\mathrm{CaF}_{2}$. Last, $\mathrm{KOH}$ was added. The amount of $\mathrm{KOH}$ was calculated based on the mole ratios of reaction 1 plus a selected molar excess $\mathrm{KOH}$. In all pilot-scale tests, the $\mathrm{KOH}$ was mixed into the $\mathrm{CeO}_{2}$ mixture. The masses of reactants are provided in Table 3-4. For all pilot-scale tests, the boat was heated to $700{ }^{\circ} \mathrm{C}$ at atmospheric pressure, held for $10 \mathrm{~min}$, evacuated, and then heated to $950{ }^{\circ} \mathrm{C}$ for a set amount of time. Following each distillation experiment, the concentration of chloride or fluoride in the product boat was measured using the methods discussed in Section 3.2.3.

Table 3-4. Pilot-Scale Demonstration Test Conditions

\begin{tabular}{|c|c|c|c|c|c|c|}
\hline Test & $\begin{array}{c}\mathrm{CeO}_{2} \\
(\mathrm{~g})\end{array}$ & $\begin{array}{c}\text { Halide } \\
\text { Salt }\end{array}$ & $\begin{array}{c}\text { Halide } \\
\text { Salt } \\
(\mathrm{g})\end{array}$ & $\begin{array}{c}\mathrm{KOH} \\
(\mathrm{g})\end{array}$ & $\begin{array}{c}\text { mol KOH } \\
\text { per mol } \\
\text { halide }\end{array}$ & $\begin{array}{c}\text { Time at } \\
950{ }^{\circ} \mathrm{C} \\
(\mathrm{min})\end{array}$ \\
\hline 15 & 86.3 & $\mathrm{CaCl}_{2}$ & 13.6 & 22.1 & 1.6 & 60 \\
\hline 16 & 86.3 & $\mathrm{CaCl}_{2}$ & 13.6 & 22.0 & 1.6 & 60 \\
\hline 17 & 86.4 & $\mathrm{CaCl}_{2}$ & 13.6 & 22.0 & 1.6 & 60 \\
\hline 18 & 86.3 & $\mathrm{CaCl}_{2}$ & 13.7 & 19.3 & 1.4 & 60 \\
\hline 19 & 231.9 & $\mathrm{CaCl}_{2}$ & 36.7 & 51.6 & 1.4 & 60 \\
\hline $19 \mathrm{~b}$ & \multicolumn{7}{|c|}{ Continuation of previous test } \\
\hline \multicolumn{7}{|c|}{200.1} \\
\hline
\end{tabular}

\subsubsection{Reactions with Plutonium Compounds}

Two tests were performed separately to evaluate the reaction of alkali hydroxide with $\mathrm{PuO}_{2}$ and with $\mathrm{PuF}_{3}$. In the first test, $\mathrm{NaOH}$ reacted with $\mathrm{PuO}_{2}$ that also contained about $3.3 \mathrm{wt} \%$ chlorides, including measurable amounts of $\mathrm{CaCl}_{2}$. The $\mathrm{PuO}_{2}$ sample $(7.833 \mathrm{~g})$ was mixed with $\mathrm{NaOH}$ (3.705 g) in a quartz crucible [2 moles of $\mathrm{NaOH}$ per mole of $\mathrm{PuO}_{2}$ plus $60 \%$ molar excess]. A quartz cover was placed over the material. The crucible was placed in the glovebox VSD apparatus and heated under vacuum to $950{ }^{\circ} \mathrm{C}$ for $60 \mathrm{~min}$. The crucible was cooled to room temperature under vacuum and the contents of the crucible sampled for XRD.

In the second test, $\mathrm{PuF}_{3}$ was prepared by heating $5.72 \mathrm{~g}$ of $\mathrm{PuO}_{2}$ with $7.03 \mathrm{~g}$ of ammonium bifluoride $\left(\mathrm{NH}_{4} \mathrm{~F}-\mathrm{HF}\right)$ in an alumina crucible under an argon gas purge for $30 \mathrm{~min}$ at $150{ }^{\circ} \mathrm{C}$, $60 \mathrm{~min}$ at $300{ }^{\circ} \mathrm{C}$, and $90 \mathrm{~min}$ at $450{ }^{\circ} \mathrm{C}$. Next, $6.093 \mathrm{~g}$ of resulting material, predominantly $\mathrm{PuF}_{3}$ (Figure 4-4), was mixed with $7.062 \mathrm{~g}$ of $\mathrm{KOH}$ and placed in a quartz crucible. A quartz cover was placed over the material. The crucible was placed in the glovebox VSD apparatus and heated under vacuum to $950{ }^{\circ} \mathrm{C}$ for $60 \mathrm{~min}$. The crucible was cooled to room temperature under vacuum. Samples of the materials before and after VSD were submitted for XRD. 


\subsection{Results and Discussion}

\subsection{Distillation of Alkali Hydroxides and Alkali Fluorides}

Evaporation rate data under VSD conditions were collected at $700-1000{ }^{\circ} \mathrm{C}$ for $\mathrm{NaF}, \mathrm{KF}, \mathrm{NaOH}$ in $\mathrm{CeO}_{2}$, and $\mathrm{KOH}$ in $\mathrm{CeO}_{2}$. The data are listed in Table 4-1. Although they do not directly indicate feasibility of the overall process, they do demonstrate that the evaporation rates of KF are roughly an order of magnitude greater than $\mathrm{NaF}$, and that the evaporation rate of $\mathrm{KOH}$ from $\mathrm{CeO}_{2}$ is measurably greater (1.5 to 3 times) than the evaporation rate of $\mathrm{NaOH}$ from $\mathrm{CeO}_{2}$. During the development of the HB-Line system for chloride removal, a nominal evaporation target was arbitrarily set at $\sim 1 \mathrm{~g} / \mathrm{min}^{[6]}$ Materials of construction limitations restrict the maximum operating temperature to $\sim 982{ }^{\circ} \mathrm{C} .{ }^{[3]}$ Consequently, the data in Table 4-1 suggest that $\mathrm{NaOH}$ and its reaction byproduct $(\mathrm{NaF})$ are not sufficiently volatile to meet the targets used for chloride salt removal by VSD. The process can still work with $\mathrm{NaOH}$ and $\mathrm{NaF}$, but the rates with $\mathrm{KOH}$ and $\mathrm{KF}$ are more in line with the processing rates desired for production-scale operations. Consequently, $\mathrm{KOH}$ is the preferred salt for converting fluoride salts with limited volatility to a more-volatile compound.

Table 4-1. Salt Evaporation Rates under VSD Conditions

\begin{tabular}{|l|c|c|c|c|c|c|}
\hline & Distill Time & \multicolumn{5}{|c|}{ Evaporation Rate (g/min) } \\
\cline { 3 - 6 } Matrix & (min) & $\mathbf{8 5 0}^{\circ} \mathbf{C}$ & $\mathbf{9 0 0}{ }^{\circ} \mathbf{C}$ & $\mathbf{9 5 0}{ }^{\circ} \mathbf{C}$ & $\mathbf{1 0 0 0}{ }^{\circ} \mathbf{C}$ & \\
\hline $\mathrm{NaF}$ & 20 & 0.024 & 0.044 & 0.086 & 0.214 \\
\hline $\mathrm{KF}$ & 20 & 0.164 & 0.517 & 0.896 & $\mathrm{NM}$ & \\
\hline \multicolumn{7}{|c|}{} \\
\hline
\end{tabular}

\subsection{Reaction of Halides with Alkali Hydroxide}

The first tests to study the reaction chemistry used $\mathrm{CaCl}_{2}$ instead of $\mathrm{CaF}_{2}$ or $\mathrm{CeF}_{3}$. There are two reasons. First, the presence of residual chloride can be determined immediately using chloride test strips. Second, previous VSD work had already shown that $\mathrm{CaCl}_{2}$ could not be sufficiently distilled using the VSD flowsheet deployed in HB-Line, even above $1000{ }^{\circ} \mathrm{C}^{[11]}$ When $\mathrm{NaOH}$ was reacted with $\mathrm{CaCl}_{2}$ at $950{ }^{\circ} \mathrm{C}$ and then distilled, the residual chloride content in the product was $<50 \mathrm{mg} / \mathrm{kg}$. This test provided initial indication that the desired reactions occurred with $\mathrm{CaCl}_{2}$.

Subsequent experiments reacted $\mathrm{KOH}$ with $\mathrm{CaF}_{2}$ and $\mathrm{CeF}_{3}$; the experiments were conducted sideby-side. The final product from each product crucible was analyzed using XRD, which has a nominal detection limit of $0.5 \mathrm{wt} \%$. The starting $\mathrm{CaF}_{2}$ concentration was $\sim 18$ wt $\%$ and the starting $\mathrm{CeF}_{3}$ concentration was $\sim 25$ wt $\%$ in $\mathrm{KOH}$. The XRD spectra are provided in Figure 4-1 (for $\mathrm{CeF}_{3}$ ) and Figure 4-2 (for $\mathrm{CaF}_{2}$ ). For both products, XRD shows no presence of fluoride or residual $\mathrm{KOH}$. Residual $\mathrm{KOH}$ would appear in the spectrum as $\mathrm{KOH}, \mathrm{KOH}$ hydrate, or potassium carbon $\left(\mathrm{K}_{2} \mathrm{CO}_{3}\right)$, depending on the extent of exposure to air and moisture. It is worth 
noting that due to splattering during the evaporation of the $\mathrm{KOH}$ that some of the $\mathrm{CeO}_{2}$ product ended up in the $\mathrm{CaO}$. These results show that VSD can remove fluoride from $\mathrm{CaF}_{2}$ and $\mathrm{CeF}_{3}$ below $1000{ }^{\circ} \mathrm{C}$, which is not practical without first reacting the salt with the alkali hydroxide.

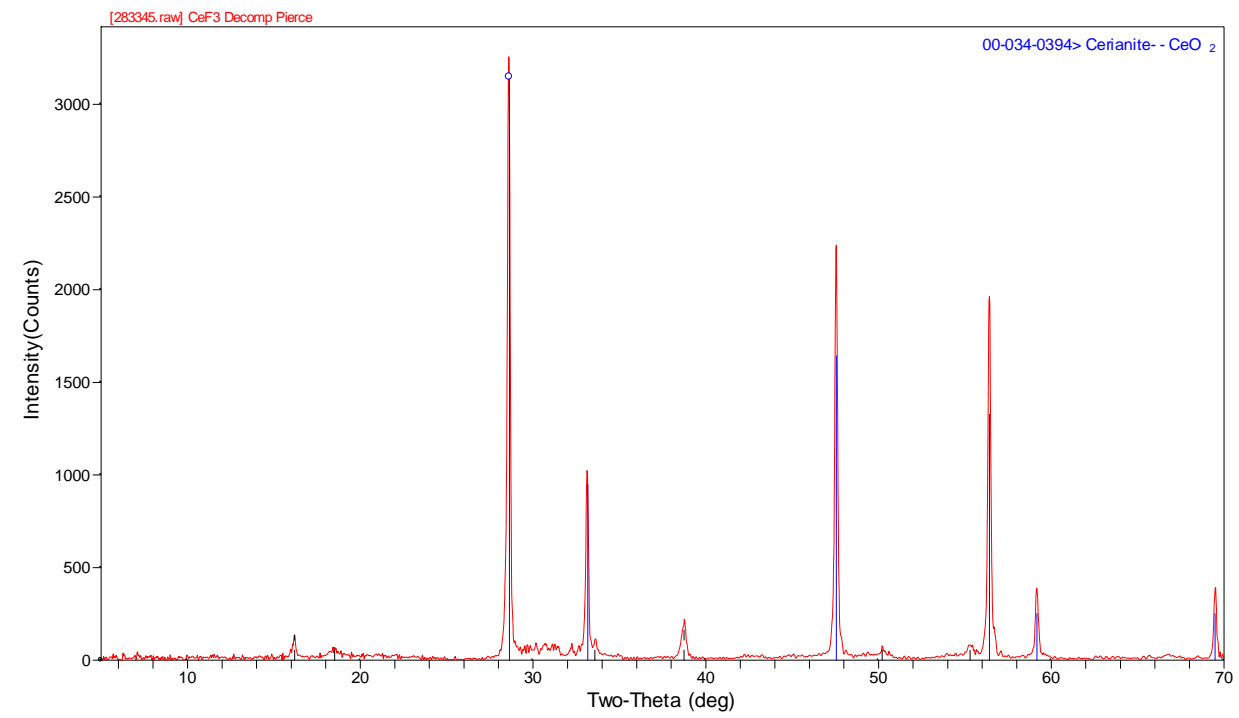

Figure 4-1. Product from Reaction of $\mathrm{CeF}_{3}$ with $\mathrm{KOH}$ followed by VSD

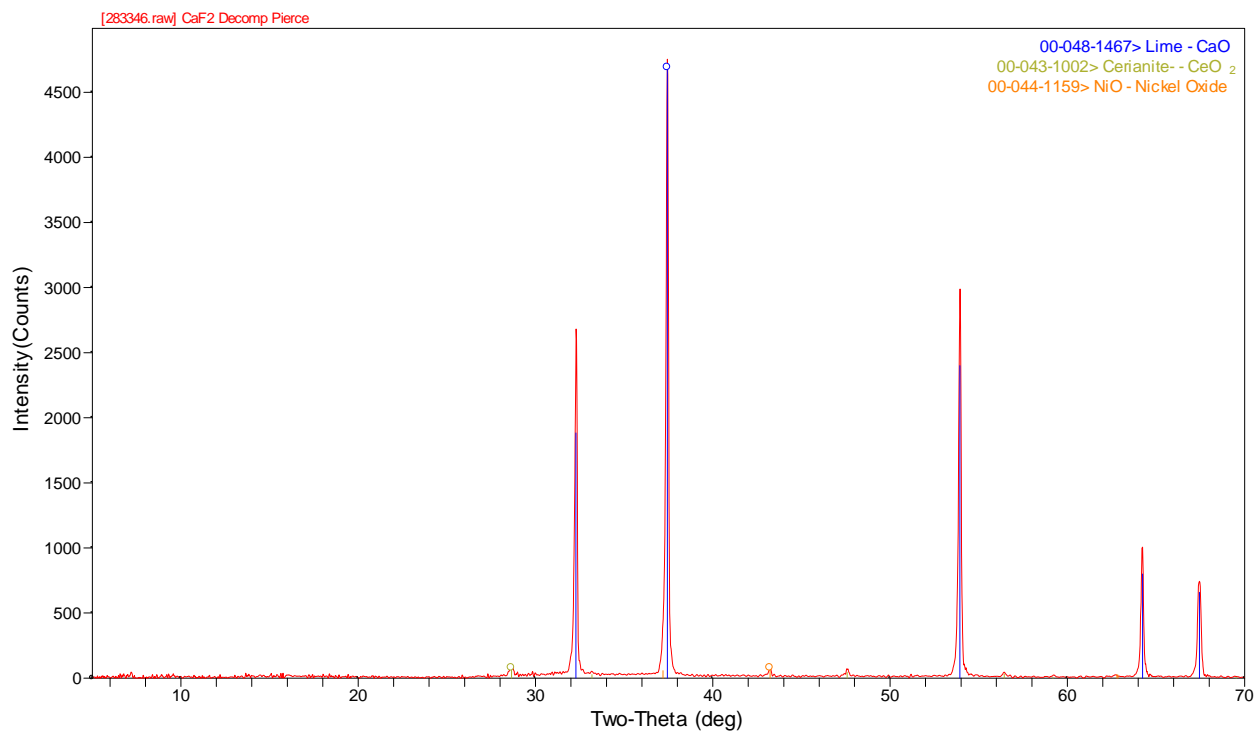

Figure 4-2. Product from Reaction of $\mathrm{CaF}_{2}$ with $\mathrm{KOH}$ followed by VSD

The presence of product splattering in the previous test raised a concern about whether conditions could be identified which would allow reaction of $\mathrm{KOH}$ with the halide salt at a temperature before significant $\mathrm{KOH}$ evaporation occurred. Experiments were completed that reacted $\mathrm{CaF}_{2}$ with $\mathrm{KOH}$ in a $\mathrm{CeO}_{2}$ matrix in air at $400{ }^{\circ} \mathrm{C}, 475{ }^{\circ} \mathrm{C}, 550{ }^{\circ} \mathrm{C}$, and $625^{\circ} \mathrm{C}$. All four temperatures are above the melting point $\left(\sim 360{ }^{\circ} \mathrm{C}\right)$ for $\mathrm{KOH}$. In all four tests, the $\mathrm{KOH}$ had already reacted with $\mathrm{CaF}_{2}$ to produce either $\mathrm{Ca}(\mathrm{OH})_{2}$ or $\mathrm{CaO}$. XRD of the product from $400{ }^{\circ} \mathrm{C}$ test showed $\mathrm{CeO}_{2}, \mathrm{~K}_{2} \mathrm{CO}_{3}-1.5 \mathrm{H}_{2} \mathrm{O}$ (reaction of $\mathrm{KOH}$ with air), and $\mathrm{Ca}(\mathrm{OH})_{2}$. Analyses of products from tests at $475{ }^{\circ} \mathrm{C}, 550{ }^{\circ} \mathrm{C}$, and $625{ }^{\circ} \mathrm{C}$ identified $\mathrm{CeO}_{2}, \mathrm{~K}_{2} \mathrm{CO}_{3}-1.5 \mathrm{H}_{2} \mathrm{O}$, and $\mathrm{CaO}$. The four tests exhibit 
that $\mathrm{KOH}$ will begin reacting with $\mathrm{CaF}_{2}$ (and presumably $\mathrm{CaCl}_{2}$ and $\mathrm{CeF}_{3}$ ) by the time the boat temperature reaches $400{ }^{\circ} \mathrm{C}$. This result means that it is unlikely that a special heating cycle will be required to react $\mathrm{KOH}$ with the halide salts prior to the onset of significant $\mathrm{KOH}$ evaporation.

\subsection{Small-Scale Process Demonstration}

The MOX feed specification for fluoride in $\mathrm{PuO}_{2}$ is $7500 \mathrm{mg} / \mathrm{kg}$. Of the impure $\mathrm{PuO}_{2}$ materials in storage that do not meet the MOX specification because of fluoride contamination, all have fluoride concentrations below 4.5 wt $\%$ (or $45,000 \mathrm{mg} / \mathrm{kg}$ ). Consequently, fluoride removal tests were run on $\mathrm{CeO}_{2}$ combined with $4.5 \mathrm{wt} \%$ fluoride as $\mathrm{CaF}_{2}$. When, as mentioned earlier, $\mathrm{CaCl}_{2}$ was used instead of $\mathrm{CaF}_{2}$ because of the ability to immediately analyze for chloride, tests were run at a nominal chloride concentration of $8.4 \mathrm{wt} \%$. On a mole percent basis, $4.5 \mathrm{wt} \%$ fluoride and $8.4 \mathrm{wt} \%$ chloride yield the same molar concentration of halide.

Eleven experiments were completed with $\sim 8.4 \mathrm{wt} \%$ chloride in $\mathrm{CeO}_{2}$ and three experiments with $\sim 4.5$ wt \% fluoride in $\mathrm{CeO}_{2}$ were also conducted. The data are listed in Table 4-2. The data in Table 4-2 address two process parameters, location of $\mathrm{KOH}$ and the amount of excess $\mathrm{KOH}$ needed to meet the MOX specification. Regarding the location of $\mathrm{KOH}$, the easiest approach would be to place the $\mathrm{KOH}$ either above or below the oxide material in the boat. If placed above, it is hoped that the $\mathrm{KOH}$ will melt, diffuse through the product, and react with the halides. If placed below, the $\mathrm{KOH}$ can melt, diffuse through the product, and be forced to react with the halides as it is drawn through the product during evaporation.

Table 4-2. Small-Scale Demonstration Test Conditions

\begin{tabular}{|c|c|c|c|c|c|c|c|}
\hline Test & $\begin{array}{c}\mathrm{CeO}_{2} \\
\text { (g) }\end{array}$ & $\begin{array}{l}\text { Halide } \\
\text { Content }\end{array}$ & $\begin{array}{l}\text { \% KOH } \\
\text { Molar } \\
\text { Excess }\end{array}$ & $\begin{array}{c}\mathrm{KOH} \\
\text { location }\end{array}$ & $\begin{array}{l}\text { Product } \\
\text { Chloride } \\
\text { (mg/kg) }\end{array}$ & $\begin{array}{l}\text { Product } \\
\text { Fluoride } \\
\text { (mg/kg) }\end{array}$ & $\begin{array}{l}\text { \% Halide } \\
\text { Removed }\end{array}$ \\
\hline 1 & 21.5 & 8.7 wt \% $\mathrm{Cl}^{-}$ & 0 & top & 25977 & --- & 70.1 \\
\hline 2 & 21.5 & $8.7 \mathrm{wt} \% \mathrm{Cl}^{-}$ & 0 & bottom & 4171 & $\begin{array}{ll}-- \\
--\end{array}$ & 95.2 \\
\hline 3 & 21.5 & $8.7 \mathrm{wt} \% \mathrm{Cl}^{-}$ & 0 & bottom & 6328 & --- & 92.8 \\
\hline 4 & 21.5 & 8.7 wt \% $\mathrm{Cl}^{-}$ & 0 & mixed & 6825 & --- & 92.2 \\
\hline 5 & 21.5 & 8.7 wt \% $\mathrm{Cl}^{-}$ & 0 & mixed & 11468 & --- & 86.9 \\
\hline 6 & 21.5 & $8.7 \mathrm{wt} \% \mathrm{Cl}^{-}$ & 0 & mixed & 8927 & --- & 89.8 \\
\hline 7 & 21.5 & $8.7 \mathrm{wt} \% \mathrm{Cl}^{-}$ & 0 & mixed & 11086 & --- & 87.3 \\
\hline 8 & 21.5 & $8.1 \mathrm{wt} \% \mathrm{Cl}^{-}$ & 60 & mixed & 1318 & --- & 98.4 \\
\hline 9 & 21.5 & $8.1 \mathrm{wt} \% \mathrm{Cl}^{-}$ & 60 & bottom & 1739 & --- & 97.9 \\
\hline 10 & 21.5 & $8.1 \mathrm{wt} \% \mathrm{Cl}^{-}$ & 60 & mixed & 2168 & --- & 97.3 \\
\hline 11 & 21.5 & 8.1 wt $\% \mathrm{Cl}^{-}$ & 140 & mixed & 457 & --- & 99.4 \\
\hline 12 & 21.5 & $4.5 \mathrm{wt} \% \mathrm{~F}^{-}$ & 0 & mixed & --- & 17582 & 60.9 \\
\hline 13 & 21.5 & $4.5 \mathrm{wt}^{\circ} \mathrm{F}^{-}$ & 40 & mixed & --- & 6608 & 85.3 \\
\hline $13 \mathrm{~b}$ & \multicolumn{4}{|c|}{ Continuation of previous test } & --- & 3776 & 91.6 \\
\hline 14 & 21.5 & 4.5 wt $\% \mathrm{~F}^{-}$ & 80 & mixed & --- & 2341 & 94.8 \\
\hline $14 \mathrm{~b}$ & \multicolumn{4}{|c|}{ Continuation of previous test } & --- & $<494$ & $>98.9$ \\
\hline \multicolumn{8}{|c|}{ 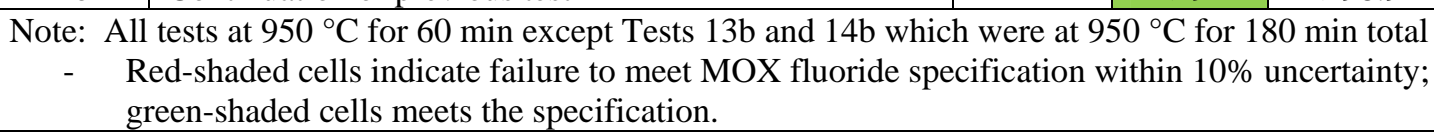 } \\
\hline
\end{tabular}

A comparison of the data from Tests 1 and 2 show that placing the $\mathrm{KOH}$ on top of the material being processed is not a viable option. Although $70 \%$ of the halide is removed, it is apparent that the $\mathrm{KOH}$ did not diffuse far enough into the product. The halide-removal performance would 
likely be worse for deeper product beds. Comparison of Tests 2-3 with Tests 4-7 indicate that placing the $\mathrm{KOH}$ at the bottom of the boat performs better than mixing the $\mathrm{KOH}$ throughout the product. However, the data in Table 4-2 do not assess an important process impact of placing the $\mathrm{KOH}$ beneath the product. That is, in most cases, during the evaporation of $\mathrm{KOH}$, entrainment of $\mathrm{CeO}_{2}$ was a problem. The quantities of $\mathrm{CeO}_{2}$ lost from the boat were not quantified because of the difficulty of separating the $\mathrm{CeO}_{2}$ from the distilled salt. The same issues were not prevalent when the $\mathrm{KOH}$ was mixed in the material. Consequently, the current recommendation involves mixing the $\mathrm{KOH}$ with the feed material prior to processing.

The data also show that even when the $\mathrm{KOH}$ is mixed into the material, some controls have to be placed on the heating rate under vacuum. The method successfully used for these tests was a rapid heating ( $\sim 14 \mathrm{~min})$ to $700{ }^{\circ} \mathrm{C}$ at atmospheric pressure, a brief dwell time ( $\left.\sim 10 \mathrm{~min}\right)$, evacuation, and rapid heating ( $\sim 10 \mathrm{~min})$ to $950{ }^{\circ} \mathrm{C}$. A slower heating rate under vacuum may be sufficient to control the evaporation rate of $\mathrm{KOH}$, but it was not evaluated.

At some point in the future, it may be possible to demonstrate that, with proper boat design, the $\mathrm{KOH}$ can be loaded directly into the bottom of the boat, the feed material laid over it, and the boat heated rapidly under vacuum to $950{ }^{\circ} \mathrm{C}$. Such an approach would simplify operations, but was not the subject of a feasibility demonstration.

The data in Table 4-2 also provide an estimate of the amount of excess $\mathrm{KOH}$ required to remove a particular amount of halide when the $\mathrm{KOH}$ is mixed into the feed material. Tests with $\mathrm{CaCl}_{2}$ (Tests 1-11) show that using no excess $\mathrm{KOH}$ will likely result in a product that does not meet the MOX specification for fluoride (assuming fluoride and chloride behave the same). The data in Table $4-2$ also show that $140 \%$ molar excess of $\mathrm{KOH}$ is an unnecessarily large amount. The use of $60 \%$ molar excess consistently meets the MOX specification with margin for error and uncertainty.

For the removal of $\mathrm{CaF}_{2}$ (Tests 12-14), two observations were made. First, because KF is not as volatile as $\mathrm{KCl}$ (Figure 2-1), it takes longer for KF to distill. Comparison of the data from Tests 13 and $13 \mathrm{~b}$ and Tests 14 and 14b depicts the impact of heating for three hours instead of one hour. A sizable decrease in residual fluoride in the product occurs. The second observation is that, similar to $\mathrm{CaCl}_{2}$ removal, the use of $40-60 \%$ molar excess $\mathrm{KOH}$ is suitable for $\mathrm{CaF}_{2}$ removal.

\subsection{Pilot-Scale Process Demonstration}

The small-scale data (Table 4-2) provided the conditions for pilot-scale testing (Table 4-3). Four tests with $\mathrm{CaCl}_{2}$ were completed using $100 \mathrm{~g}$ of feed (not counting $\mathrm{KOH}$ ) and one test (Test 19/19b) was performed with $268.6 \mathrm{~g}$ of feed. Figure 3-6 shows the two boats used for pilotscale testing. The boat on the left was used for the $100-\mathrm{g} \mathrm{CaCl}_{2}$ tests; the boat on the right was used for the 268.6-g $\mathrm{CaCl}_{2}$ test and the pilot-scale test with $\mathrm{CaF}_{2}$ (Test 20). The significance of the boat on the right (Figure 3-6) is that it is of the same general design as the boat used in HBLine. ${ }^{[12]}$ Consequently, Tests 19/19b and 20 give a strong indication of how effective fluoride removal can be in a VSD system similar in design to the system deployed in HB-Line.

At the 100 -g scale, the data in Table $4-3$ show that both $40 \%$ and $60 \%$ molar excess of $\mathrm{KOH}$ are sufficient to meet the MOX specification after $60 \mathrm{~min}$ at $950{ }^{\circ} \mathrm{C}$. However, at the 268.6-g scale, because of the greater product depth, 180 min was needed to achieve excellent halide removal (>99.0\%). Due to the light, fluffy nature of the $\mathrm{CaF}_{2}$ used, only $220.5 \mathrm{~g}$ of feed could be loaded into the boat for the pilot-scale removal of fluoride (versus $268.6 \mathrm{~g}$ for chloride removal). Only $40 \%$ molar excess of $\mathrm{KOH}$ was needed to remove greater than $99.0 \%$ of the fluoride after 
$180 \mathrm{~min}$. The potential exists to further reduce the amount of the $\mathrm{KOH}$ added for fluoride removal.

Table 4-3. Pilot-Scale Demonstration Test Conditions

\begin{tabular}{|c|c|c|c|c|c|c|c|}
\hline Test & $\begin{aligned} & \mathrm{CeO}_{2} \\
&+ \text { Halide } \\
& \text { Salt (g) }\end{aligned}$ & $\begin{array}{c}\text { Halide } \\
\text { Content }\end{array}$ & $\begin{array}{l}\text { \% KOH } \\
\text { Molar } \\
\text { Excess }\end{array}$ & $\begin{array}{c}\mathrm{KOH} \\
\text { location }\end{array}$ & $\begin{array}{l}\text { Product } \\
\text { Chloride } \\
(\mathrm{mg} / \mathrm{kg})\end{array}$ & $\begin{array}{l}\text { Product } \\
\text { Fluoride } \\
(\mathrm{mg} / \mathrm{kg})\end{array}$ & $\begin{array}{l}\text { \% Halide } \\
\text { Removed }\end{array}$ \\
\hline 15 & 99.9 & 8.7 wt $\% \mathrm{Cl}^{-}$ & 60 & mixed & 1178 & ---- & 98.7 \\
\hline 16 & 99.9 & $8.7 \mathrm{wt} \% \mathrm{Cl}^{-}$ & 60 & mixed & 3192 & --- & 96.3 \\
\hline 17 & 100.0 & $8.7 \mathrm{wt} \% \mathrm{Cl}^{-}$ & 60 & mixed & 925 & $\begin{array}{ll}--- \\
\end{array}$ & 98.9 \\
\hline 18 & 100.0 & $8.7 \mathrm{wt} \% \mathrm{Cl}^{-}$ & 40 & mixed & 1307 & $\begin{array}{ll}--- \\
\end{array}$ & 98.5 \\
\hline 19 & 268.6 & $8.7 \mathrm{wt} \% \mathrm{Cl}^{-}$ & 40 & mixed & 6516 & ---- & 92.5 \\
\hline $19 \mathrm{~b}$ & \multicolumn{4}{|c|}{ Continuation of previous test } & 516 & --- & 99.4 \\
\hline 20 & 220.5 & $4.5 \mathrm{wt}^{0} \mathrm{~F}^{-}$ & 40 & mixed & ---- & $<465$ & $>99.0$ \\
\hline \multicolumn{8}{|c|}{$\begin{aligned} \text { Note: } & \text { All tests at } 950{ }^{\circ} \mathrm{C} \text { for } 60 \text { min except Tests } 19 \mathrm{~b} \text { and } 20 \text { which were at } 950{ }^{\circ} \mathrm{C} \text { for } 180 \text { min total } \\
\text { - } & \text { Red-shaded cells indicate failure to meet } \mathrm{MOX} \text { fluoride specification within } 10 \% \\
& \text { uncertainty; green-shaded cells meets the specification. }\end{aligned}$} \\
\hline
\end{tabular}

One other important point can be drawn from a comparison of data in Table 4-2 with Table 4-3. Although the amount of data is limited, the same amount of $\mathrm{KOH}$ molar excess seems to yield better results as the bed depth increases (Tests $8-10,16-18$ vs. 19; Test 13/13b vs. 20). This result is consistent with the data in Table 4-2 which showed that placing the $\mathrm{KOH}$ at the bottom of the boat yielded better results than mixing the $\mathrm{KOH}$ with feed material.

\subsection{Reactions with Plutonium Compounds}

Although more data related to plutonium $(\mathrm{Pu})$ will be required to fully demonstrate a VSD process for fluoride removal, proof of feasibility required two questions to be answered. First, does $\mathrm{PuO}_{2}$ react with $\mathrm{KOH}$ and form some other $\mathrm{Pu}$ compound? If so, a potential issue would exist. Second, does $\mathrm{PuF}_{3}$ react with $\mathrm{KOH}$ to form $\mathrm{PuO}_{2}$ ? If not, a different issue would exist.

In the first radioactive test, $\mathrm{PuO}_{2}$ with some $\mathrm{CaCl}_{2}$ present was reacted with $\mathrm{NaOH}$ and distilled. However, during the test, the quartz lid over the crucible fell into the crucible and created a situation where the $\mathrm{PuO}_{2}$ and $\mathrm{NaOH}$ were trapped between two quartz layers with no direct path for materials to distill. Significant effort was required to remove the cover and obtain a sample. The XRD analysis of the sample is shown in Figure 4-3. The analysis shows that the $\mathrm{PuO}_{2}$ did not form an alternate $\mathrm{Pu}$ compound, but rather remained $\mathrm{PuO}_{2}$. Also, no $\mathrm{NaOH}$ remained in the system. Last, the data suggest that the $\mathrm{CaCl}_{2}$ was converted to $\mathrm{NaCl}$, but was unable to distill. This last point is speculation based on what was known about the sample. Regardless, the primary point is that the first question mentioned above was answered $-\mathrm{PuO}_{2}$ did not react with $\mathrm{NaOH}$ to form a different Pu compound. 


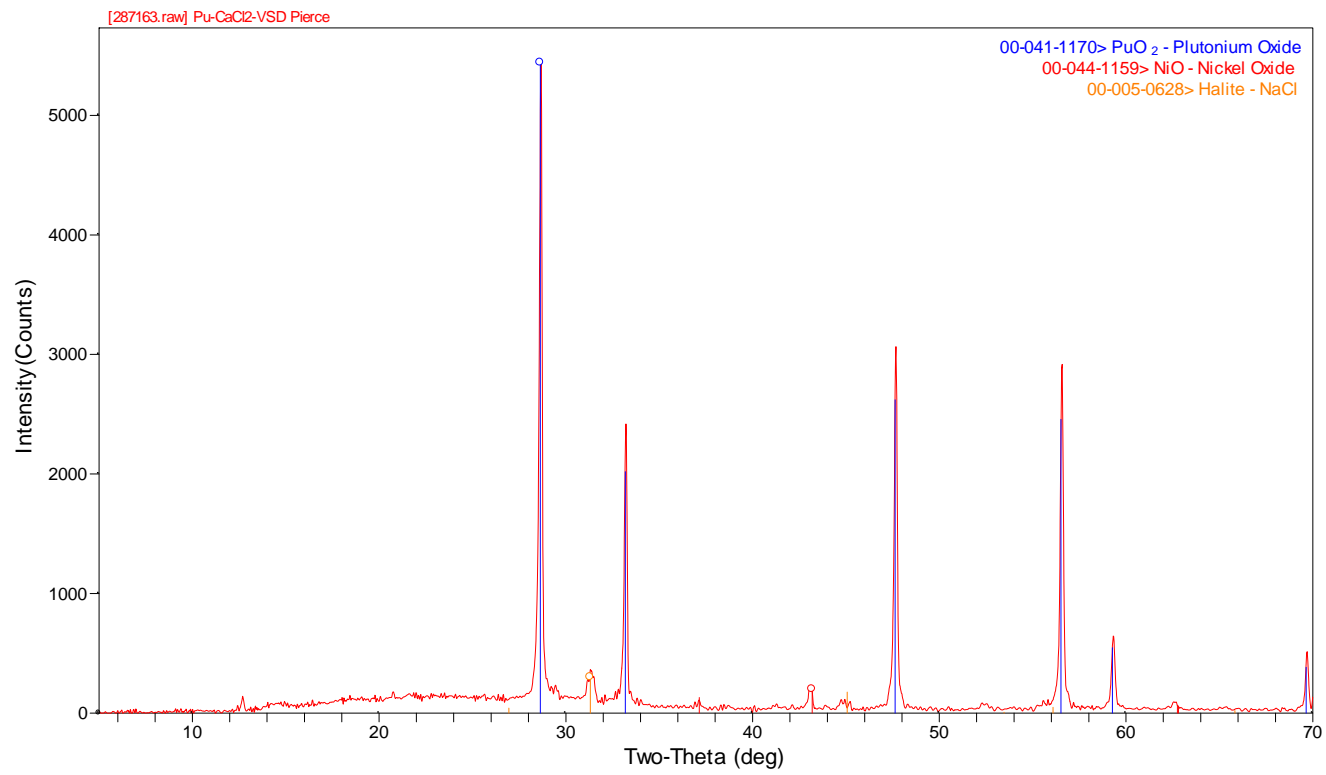

Figure 4-3. $\mathrm{PuO}_{2}$ after Reaction with $\mathrm{NaOH}$ followed by VSD

In the second radioactive test, $\mathrm{PuF}_{3}$ was reacted with $\mathrm{KOH}$ and distilled. XRD analyses of the initial and final compounds were obtained and are provided in Figure 4-4 (before) and Figure 4-5 (after). The data show that the $\mathrm{PuF}_{3}$ was completely converted to $\mathrm{PuO}_{2}$, and that no residual $\mathrm{KOH}$ was present in the product. This result addresses the second feasibility question mentioned above. It should be noted that the starting material was primarily $\mathrm{PuF}_{3}$, but it did contain a minor amount of a Pu-ammonium-fluoride compound (analog to $\mathrm{KU}_{6} \mathrm{~F}_{25}$ in Figure 4-4 data). The $\mathrm{Pu}$ ammonium fluoride was a byproduct of the method (ammonium bifluoride fusion) used to produce the $\mathrm{PuF}_{3}$ sample. It is also worth noting that, similar to the previous test, $\mathrm{KOH}$ did not react with $\mathrm{Pu}$ to form a compound other than $\mathrm{PuO}_{2}$.

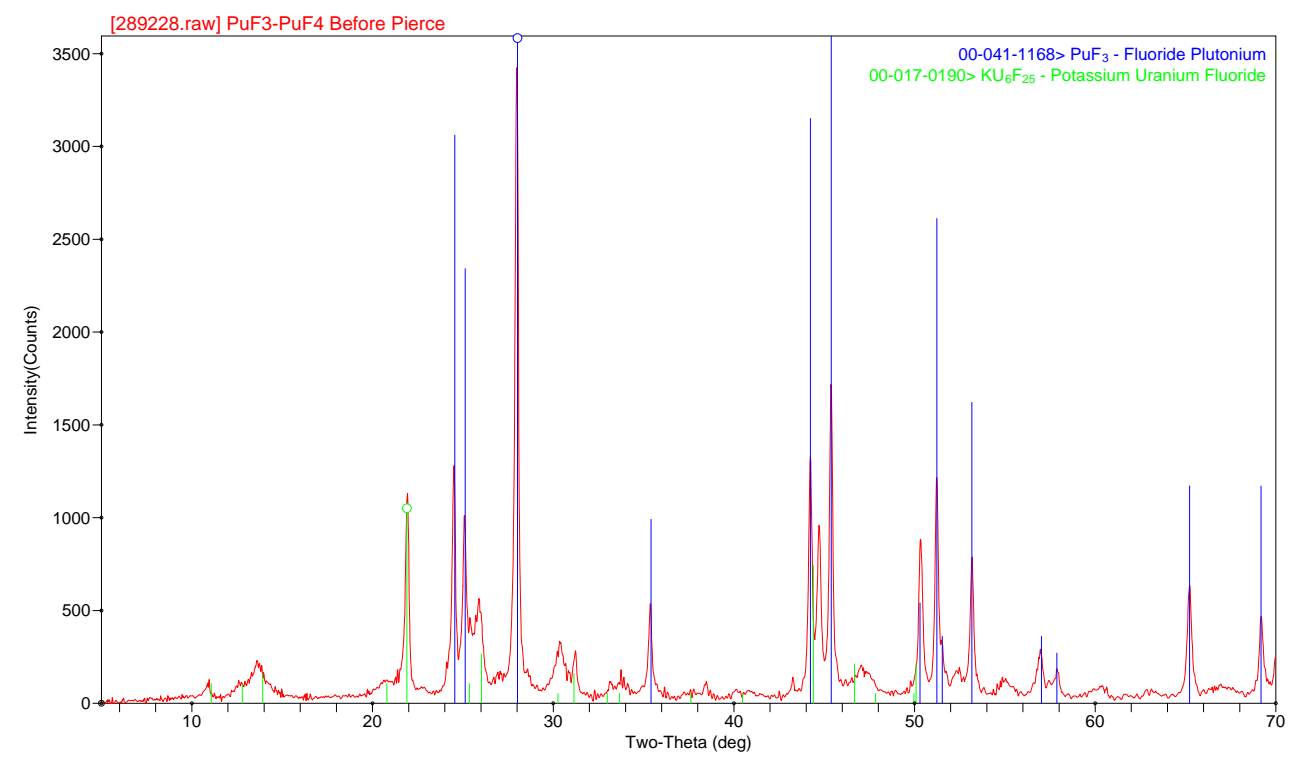

Figure 4-4. $\mathrm{PuF}_{3}$ before Reaction with $\mathrm{KOH}$ 


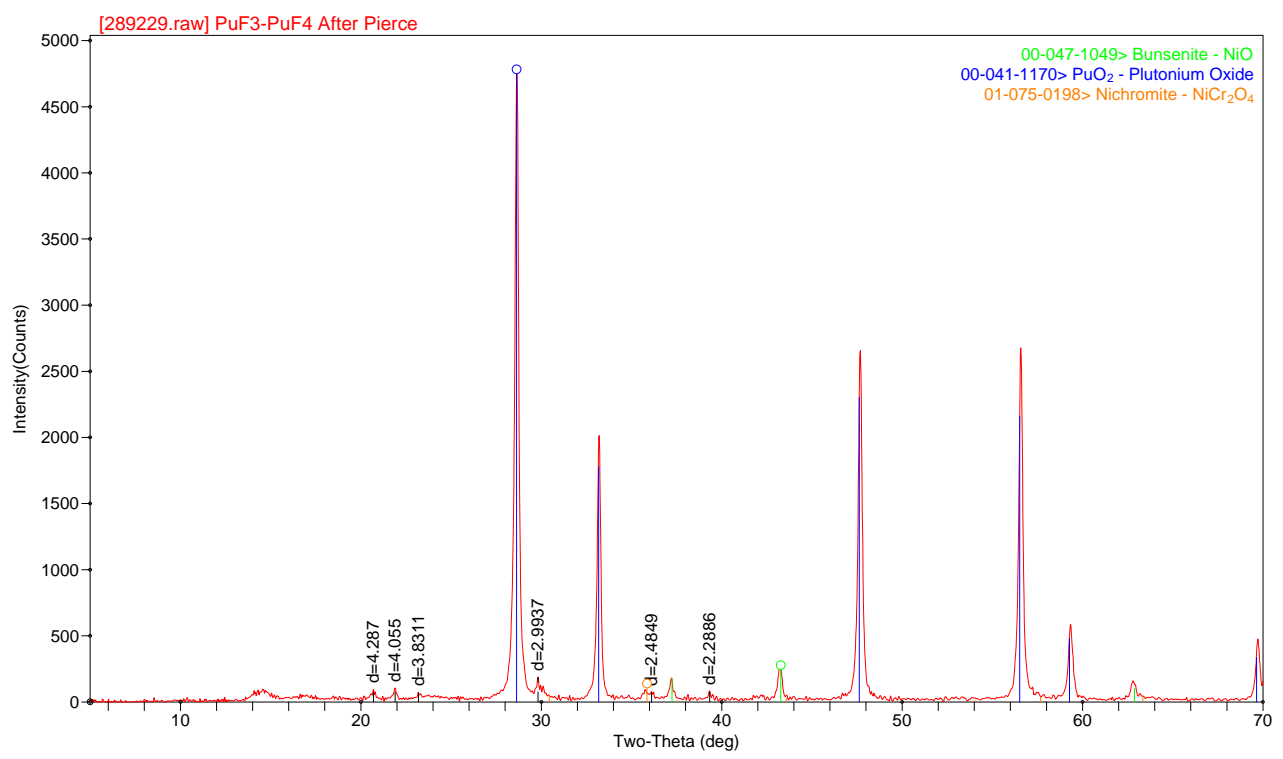

Figure 4-5. $\mathrm{PuF}_{3}$ after Reaction with $\mathrm{KOH}$ followed by VSD

\subsection{Important Mechanical Design Considerations}

During the deployment in HB-Line of a VSD system for $\mathrm{NaCl} / \mathrm{KCl}$ removal, two minor system modifications were required for proper performance. ${ }^{[12]}$ A baffle plate was installed on the VSD end cap to alter the flow pattern in the cooled zone which enabled salt deposition prior to it exiting the system. Also, a heat shield was attached to the feed boat to provide a thermal barrier between the cooled and heated zones which prevented the front of the feed boat from being too cold for complete salt distillation.

The use of $\mathrm{KOH}$ as a reactant introduces two significant design considerations. First, allowances must be made for the increased volatility of $\mathrm{KOH}$ compared to $\mathrm{NaCl} / \mathrm{KCl}$ (Figure 2-2). Can the $\mathrm{KOH}$ vapors be condensed before exiting the system? Early testing showed that the simple baffle on the vacuum chamber end cap would not be sufficient to promote $\mathrm{KOH}$ deposition. More importantly, a second impact was also observed. After initial VSD tests with $\mathrm{KOH}$ were performed, it was noted that $\mathrm{KOH}$ had deposited on the outside of the boat in the heated section. This behavior made it difficult to remove the boat from the vacuum chamber. Some design feature had to be identified to isolate the heated and cooled zones better to prevent backevaporation and deposition of $\mathrm{KOH}$ in the heated zone as cooling occurred.

In addition to volatility issues associated with $\mathrm{KOH}$, a second issue exists because $\mathrm{KOH}$ is extremely hygroscopic and readily absorbs moisture from the humid atmosphere of South Carolina. The absorption of moisture could complicate the cleaning of the vacuum chamber. Also, any residual $\mathrm{KOH}$ in the vacuum chamber after cleaning could make subsequent system evacuation more difficult due to absorbed moisture.

The answer to both design considerations was realized through the use of a removable liner (Figure 3-4). The purpose of the removable liner is to provide a location for salt deposition that can be removed and either discarded or cleaned in an alternate location. The installed liner is shown in Figure 3-5. Although neither the VSD vacuum chamber nor the end of the liner was tapered to provide a tight fit between them, typical salt recovery in the liner was 98-99 wt \%. It is 
expected that almost all of the salt can be collected in the liner by modifying the design of the VSD chamber and the liner to provide a tapered fit. The high salt recovery efficiencies also eliminated another concern associated with the use of a removable liner, which is having the liner get stuck in the chamber. For all liner trials, sticking of the liner was never an issue.

The use of the removable liner also provided a means for resolving the issue associated with using baffles to adequately separate the heated and cooled zones. Without the presence of a removable liner, the use of a baffle in the heated zone that was separate from the feed boat seemed impossible. If a baffle was inserted into the vacuum chamber heated zone prior to distillation, the deposition of salt in the cooled zone during processing would make it impossible to remove the baffle without first disturbing the salt layer.

However, with the removable liner, a baffle can be placed into the heated end of the liner. With placement in the heated zone, no salts deposit on or around the baffle. Consequently, once the liner is removed from the chamber, the baffle in the heated end of the liner can be easily removed. When the liner with a baffle in the heated zone was deployed, no more issues were noted with the boat getting stuck in the heated zone. The baffle provided enough of a heat shield between the heated and cooled zones to prevent $\mathrm{KOH}$ deposition in the heated zone.

It should be noted that the baffles do more than act as heat shields. They also route the flow of gases in the liner to stay close to the liner walls for longer. During testing, different baffle configurations were tested. Although their location has not been optimized, a drawing of a successful configuration is shown in Figure 4-6. Figure 4-7 shows the salt deposition pattern inside of the liner from both the heated and cooled zones using the baffle configuration shown in Figure 4-6.

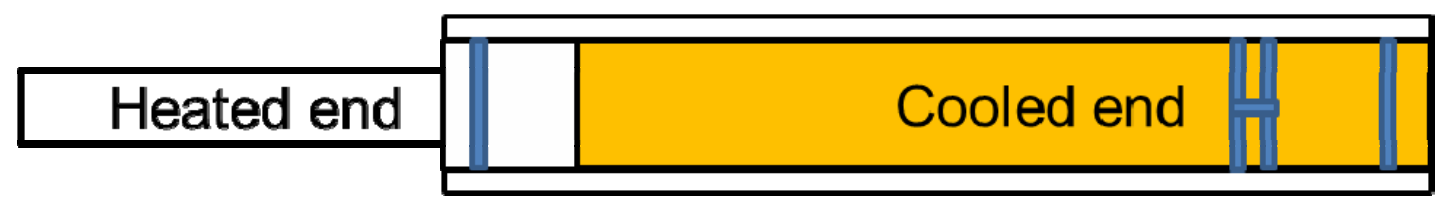

Figure 4-6. Successful Baffle Configuration inside Removable Liner

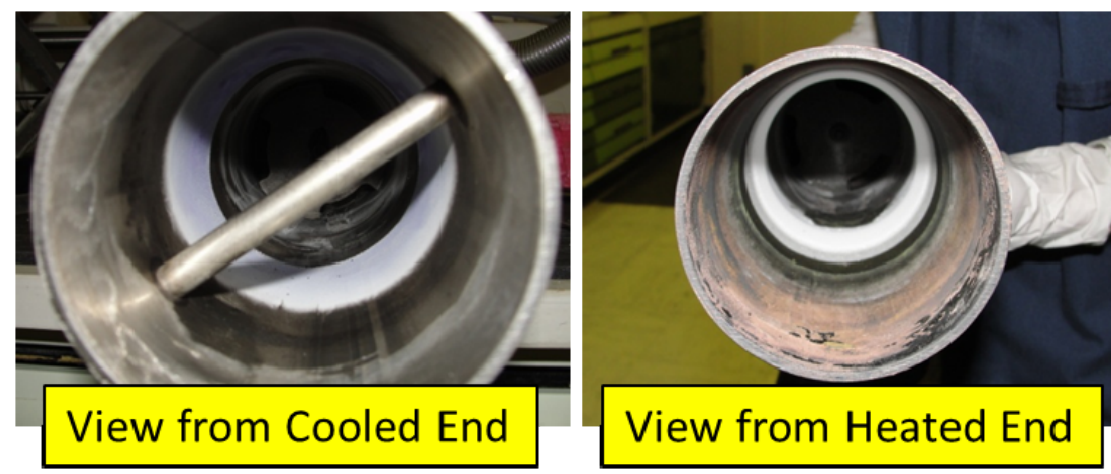

Figure 4-7. Salt Deposition Pattern inside Removable Liner

It should be noted that the removable liner, in its current design, cannot be used as a disposable liner. The liner is suitable for cleaning and multi-cycle use. Experiments have begun looking at a thin-walled collapsible liner that can be slid inside the current liner to provide the surface for salt deposition. After the distillation process, the collapsible liner can be slid from the thicker liner 
and readily size-reduced along with the salt on its surfaces. Initial investigations of this salt collection and removal alternative have shown promise.

One final potential issue that has not been addressed is the removal of water vapor from the system. According to reaction 1, water vapor is a byproduct of the reaction between $\mathrm{KOH}$ and the halide salts. The current vacuum pump used to evacuate the HB-Line VSD unit is a two-stage dry pump. SRNL used a single-stage oil pump. The two-stage dry pump is more sensitive to the presence of water vapor, which can condense in the lines of the pump and impede achievement of the vacuum levels necessary for distillation. The oil pump used for SRNL testing is not as sensitive to water vapor and has not shown any adverse effects thus far. This issue can be overcome by installing a disposable in-line moisture absorbent in the vacuum line between the vacuum chamber and the pump.

\subsection{Conclusions}

SRNL has successfully demonstrated the removal of halide from $\mathrm{CaCl}_{2}, \mathrm{CaF}_{2}$ and $\mathrm{PuF}_{3}$ below $1000{ }^{\circ} \mathrm{C}$ using VSD technology. Although, $\mathrm{NaCl}, \mathrm{KCl}$, and $\mathrm{KF}$ are sufficiently volatile that they can be distilled from $\mathrm{PuO}_{2}$ at a satisfactory rate under vacuum at $950{ }^{\circ} \mathrm{C}$; other halide salts including $\mathrm{CaCl}_{2}, \mathrm{CaF}_{2}$, and $\mathrm{PuF}_{3}$ are not. However, it has been shown that $\mathrm{KOH}$ reacts with $\mathrm{CaCl}_{2}, \mathrm{CaF}_{2}, \mathrm{CeF}_{3}, \mathrm{PuF}_{3}$ to form $\mathrm{KF}$ or $\mathrm{KCl}$, water vapor, and an oxide $\left(\mathrm{CaO}, \mathrm{CeO}_{2}\right.$, or $\mathrm{PuO}_{2}$, respectively). The reaction of $\mathrm{KOH}$ with $\mathrm{CaF}_{2}$ to form $\mathrm{CaO}$ begins below $400{ }^{\circ} \mathrm{C}$ and is complete by $475^{\circ} \mathrm{C}$. Once the reaction occurs, the products of $\mathrm{KF}, \mathrm{KCl}$, and excess $\mathrm{KOH}$ can be removed by VSD. Although $\mathrm{NaOH}$ can also be used to produce similar reactions, the NaF byproduct is not sufficiently volatile to meet the processing-rate targets used for chloride salt removal by VSD.

Small-scale process demonstrations (25-30 g feed) showed the removal of 45,000 $\mathrm{mg} / \mathrm{kg}$ fluoride (as $\mathrm{CaF}_{2}$ ) and $84,000 \mathrm{mg} / \mathrm{kg}$ chloride $\left(\mathrm{as} \mathrm{CaCl}_{2}\right.$ ) to less than $4000 \mathrm{mg} / \mathrm{kg}$ using $40-60 \%$ molar excess of $\mathrm{KOH}$. This level of halide removal is more than adequate to meet the MOX fuel specification for fluoride of $7500 \mathrm{mg} / \mathrm{kg}$. The location of $\mathrm{KOH}$ in the feed boat is an important consideration. Placing the $\mathrm{KOH}$ at the bottom of the feed boat produces the best fluoride removal results but may lead to product loss from the boat. Mixing the $\mathrm{KOH}$ into the feed produces satisfactory fluoride removal without the loss of material from the feed boat.

Pilot-scale process demonstrations (100-270 g) using 40-60\% molar excess of $\mathrm{KOH}$ yielded better results than the small-scale tests. In a 269 -g test with $40 \%$ molar excess of $\mathrm{KOH}$, chloride (as $\mathrm{CaCl}_{2}$ ) in $\mathrm{CeO}_{2}$ was reduced from $87,000 \mathrm{mg} / \mathrm{kg}$ to $516 \mathrm{mg} / \mathrm{kg}$. In a 220 -g test with $40 \%$ molar excess of $\mathrm{KOH}$, fluoride (as $\mathrm{CaF}_{2}$ ) in $\mathrm{CeO}_{2}$ was reduced from $45,000 \mathrm{mg} / \mathrm{kg}$ to $<465 \mathrm{mg} / \mathrm{kg}$.

The introduction of $\mathrm{KOH}$ and its reaction byproducts into the process requires some changes to the way the salts are deposited and removed. To date, it appears that a removable liner with a system of multiple reusable baffles can compensate for the process changes. The reaction of $\mathrm{KOH}$ with halide salts also produced water vapor as a byproduct. This water could cause issues with the existing two-stage dry pumps used by HB-Line. However, this issue can probably be overcome by installing a disposable in-line moisture absorbent in the vacuum line between the VSD chamber and the pump.

\subsection{Future Work}

SRNL proposes a development program using available equipment that has the same internal dimensions as the VSD unit deployed in HB-Line. The program will define physical and chemical parameters needed for subsequent scale-up and deployment. As before, the majority of 
the work will be with non-radioactive materials. Testing for the development of VSD for $\mathrm{NaCl}$ and $\mathrm{KCl}$ demonstrated that non-radioactive simulants were appropriate. ${ }^{[6,10,12]}$ However, it is not known if the same will be true for $\mathrm{CaCl}_{2}, \mathrm{CaF}_{2}, \mathrm{PuF}_{3}$, and $\mathrm{PuF}_{4}$ processing.

The specific tasks follow.

1) Complete production-scale testing with $\mathrm{CaF}_{2}, \mathrm{CeF}_{3}$, and $\mathrm{CaCl}_{2}$ mixed with $\mathrm{CeO}_{2}$. Smallscale and pilot-scale testing are complete. The performance demonstrated in those tests will be proven at a 350-500-g scale.

2) Perform several tests with $\mathrm{CaF}_{2}$ and $\mathrm{CaCl}_{2}$ mixed in with $\mathrm{PuO}_{2}$. The limited amount of data with $\mathrm{PuO}_{2}$ and fluorides will be expanded to include the distillation of fluoride-bearing $\mathrm{PuO}_{2}$ materials and testing with $\mathrm{PuO}_{2}$ spiked with $\mathrm{CaF}_{2}, \mathrm{CaCl}_{2}$, and, if necessary, $\mathrm{PuF}_{3}$.

3) Identify quantities of reactants and furnace cycles for varying concentrations of fluoride. Define the process conditions that will treat most of the high-fluoride concentrations (4.5 wt \% is bounding for $>98 \%$ of fluoride-bearing items) and then determine if the flowsheet should be constant or adjusted based on fluoride concentration.

4) Determine if $\mathrm{NaCl}$ and $\mathrm{KCl}$ have a negative effect on the quantity of $\mathrm{KOH}$ required. Tests to date have focused on one halide component $\left(\mathrm{CaF}_{2}, \mathrm{CaCl}_{2}\right.$, or $\left.\mathrm{CeF}_{3}\right)$ blended with $\mathrm{CeO}_{2}$. Tests must be conducted to determine if $\mathrm{NaCl}$ and $\mathrm{KCl}$ will react with $\mathrm{KOH}$ and affect flowsheet inputs. Prior work with $\mathrm{Na}_{2} \mathrm{O}_{2}$ fusion suggests that $\mathrm{NaCl}$ and $\mathrm{KCl}$ will not negatively affect the reaction. ${ }^{[8]}$

5) Identify necessary changes or appropriate improvements for the boat design (related to $\mathrm{PuO}_{2}$ entrainment and materials), salt cleaning, and cooling. Assess whether a removable/reusable liner is a preferred alternative to current method of apparatus cleaning, especially in light of the hygroscopic nature of $\mathrm{KOH}$. Demonstrate the design changes on a production scale.

\subsection{References}

1. E. Garcia, V. Dole, and J. McNeese, "Separation of Plutonium from Chloride Salts is Demonstrated by High-Temperature Vacuum Distillation Method,” The Actinide Research Quarterly of the Nuclear Materials Technology Division, Los Alamos National Laboratory (Summer 1995).

2. B. R. Westphal, K. C. Marsden, J. C. Price, and D. V. Laug, "On the Development of a Distillation Process for the Electrometallurgical Treatment of Irradiated Spent Nuclear Fuel,” Nucl. Eng. \& Tech., 2008, 40(3), 163-174.

3. J. E. Therrell, "Vacuum Salt Distillation (VSD) in HB-Line," SRNS-N2000-2011-00032 (February 15, 2011).

4. T. D. Woodsmall, "Proof of Concept - Fluoride Compound Reactions and Distillation of Fluoride Products in VSD,” Technical Task Request NMMD-HTS-2010-3159, Rev 1 (April 27, 2011). 
5. R. A. Pierce, “Task Technical and Quality Assurance Plan for Vacuum Salt Distillation of Fluoride Salts from Plutonium Oxide,” SRNL-RP-2011-00298 (May 9, 2011).

6. D. C. Castiglione and R. A. Pierce, "Non-Radioactive Pilot-Scale Studies for the Vacuum Distillation of Chloride Salts,” SRNL-STI-2010-00075 (March 2010).

7. J. E. Laurinat, "Vapor Pressures for $\mathrm{LiF}, \mathrm{Li}_{2} \mathrm{O}, \mathrm{LiOH}$, and $\mathrm{KOH}$," SRNL-L4222-2011-00006 (February 15, 2011).

8. D. C. Castiglione and R. A. Pierce, "Non-Radioactive Studies of Sodium Peroxide Fusion for Accelerated Sample Dissolution,” SRNL-STI-2010 -00164 (June 2010).

9. O. J. Wick (ed), Plutonium Handbook. A Guide to the Technology - Volumes I \& II, American Nuclear Society (La Grange Park, IL), 1980, 352.

10. R. A. Pierce and D. C. Castiglione, "Radioactive Pilot-Scale Studies for the Distillation of Chloride Salts from 3013 DE Materials,” SRNL-STI-2010-00440 (July 2010).

11. K. M. L. Taylor-Pashow, "Vacuum Distillation of Calcium Chloride," SRNL-STI-201000334, (August 2010).

12. R. A. Pierce and T. B. Edwards, "Vacuum Salt Distillation Intermediate-Scale and FullScale Prototype Testing,” SRNL-STI-2010-00753 (December 2010). 


\section{Distribution:}
A.B. Barnes, 999-W
D.A. Crowley, 773-43A
S.D. Fink, 773-A
B.J. Giddings, 786-5A
C.C. Herman, 999-W
S.L. Marra, 773-A
A.M. Murray, 773-A
F.M. Pennebaker, 773-42A
W.E. Harris, 704-2H
J.B. Schaade, 704-2H
G.J. Zachman, 225-7H
P.B. Andrews, 704-2H
S.J. Howell, 704-2HK.A. Dukes, 221-H
M.J. Lewczyk, 221-H
K.J. Gallahue, 221-H
K.D. Scaggs, 704-2H
K.P. Burrows, 704-2H
J.E. Therrell, 704-2H
J.W. Christopher, 704-2H
R.A. Pierce, 773-A
K.M. Taylor-Pashow, 773-A
P.L. Lee, 703-41A
S.A. Thomas, 703-46A 